\title{
The Gathering of the Storm: Risks and Uncertainties in Global Warming
}

\author{
Jan-Erik Lane \\ Public Policy Institute, Belgrade \\ Address: 10 Charles Humbert, 1205 Geneva; 559 A, 3rd Floor, Thuya Street, 9th Quarter, \\ Yangon. Myanmar.
}

Received: May 8, 2017 Accepted: May 27, 2017 Online published: June 19, 2017

doi:10.5296/jpag.v7i2.11415 URL: https://doi.org/10.5296/jpag.v7i2.11415

\begin{abstract}
It is often mentioned that solar energy is becoming competitive and that modern renewables is more and more utilized. However, at the same no one speaks of the immense augmentation of air transportation and the construction of new giant infra structure facilities, for instance airports. Moreover, the number of cars increases as well as their engine size. The risk of policy failures and implementation gaps are great for the COP21 project, where one major nation already has reneged.
\end{abstract}

Keywords: Wildavsky's implementation hiatus, policy failures, common pool regime (CPR) defection or failure, the UNFCCC framework.

\section{Introduction}

While the global political community debates about the US defection from the COP21 Treaty, things are moving on in real life. The optimists about climate change argue that the objectives of COP21 are still within reach, speaking of a sustainable economy (Sachs, 2015). The pessimists point out that the $\mathrm{CO} 2$ in the atmosphere keeps augmenting. We are now at 410 ppm on the Keeling curve.

The optimists underline the many micro changes the recent years in energy production, efficiency and transformation. However, the pessimists emphasize that the macro picture remains much the same, globally speaking: more of air and sea transportation, coal replaced by oil and gas, the shale gas revolution, constantly more cars and bigger engines, wood coal and deforestation, reduction of Amazons and Borneo forests, etc.

Why have the recognition of climate change and its enormous dangers to mankind been so late and so contested by some groups? 


\section{Short History of Global Warming Theory}

The first anticipation of the global warming mechanism was done by Frenchman J. Fourier in the early $19^{\text {th }}$ century, but the theory was developed by Swedish chemist Arrhenius around 1895. He calculated that a doubling of $\mathrm{CO} 2 \mathrm{ppm}$ would be conducive to a 5 degree increase in global average temperature, which is not too far off the worst scenario for the 21 rst century, according to UN expertise now.

Yet, it was not until Stephen Schneider published Global Warming in 1989 that the theory started to receive wide attention, no doubt strengthened by the work of Keeling in measuring $\mathrm{CO} 2$ ppm globally. Moreover, techniques for viewing the $\mathrm{CO} 2$ layer were developed, increasing the attention to climate change.

Now, the UN reacted with creating a few bodies to look into the changes going on, one of which was the COP framework. The economists jumped in besides the natural scientists, worried about the future costs of this transformation of the atmosphere. On the one hand, Kaya and associates (1997) presented a model that explained CO2:s with energy and energy intensity of GDP. On the other hand, Stern (2007) called global warming the largest externality in human history, calling for international governance in order to stem the growth of greenhouse gases. Stern outlines a number of activities aimed at reducing $\mathrm{CO} 2$ emissions, promising also a Super Fund to channel money from rich advanced nations to poor countries and developing economies. As little has been done through the UN system of meetings and agencies up to date, Stern (2015) later asked: "What are we waiting for?"

All theories need confirmation. When the polar ice mountains began to collapse, it seemed decisive evidence for the global warming theory. Other important test implications like glacier retreats everywhere, ocean warming and acidification as well as desertification in Africa also gave support for global warming theory. Denials of climate change appear more and more unfounded, although it is true that more of $\mathrm{CO} 2$ may benefit some fauna or environment niches.

\section{Risks and Uncertainties}

Considering the probable damages from global warming, it is astonishing that global warming theory has not been better recognized or even conceptually developed or empirically corroborated. If global warming continues unrestrained, much of Asia will be negatively affected, just as Australia is on the verge of losing its coral reefs. There will be sooner or later:
a) Huge land losses along the costs;
b) Too high temperatures for men and women to work outside;
c) Food production decline;
d) Fish harvest decrease; 


\section{Mll Macrothink}

e) Droughts and starvation;

f) Lack of fresh water supply;

g) Drying up of rivers, affecting electricity supply;

h) Ocean acidification and species extinction;

i) Highly volatile climate with tremendous damages.

This list is far from complete or exhaustive. One could even mention worse outcomes, like the transformations of warm and cold currents in the oceans. What one may underline is that so far no known negative feedback has been found that could stem global warming naturally. We have only positive feedbacks, meaning outcomes reinforce each other in the same direction.

It is far from easy to calculate exactly how increases in greenhouse gases impact upon temperature augmentations. Take the case of $\mathrm{CO} 2 \mathrm{~s}$, where a most complicated mathematical formula is employed:

(1) $T=T c+T n$, where $\mathrm{T}$ is temperature, Tc is the cumulative net contribution to temperature from $\mathrm{CO} 2$ and $\mathrm{Tn}$ the natural one. "CO2" refers to all $\mathrm{CO} 2$, there is no distinction between man-made and natural $\mathrm{CO} 2$.

But when it comes to methane, it is not known whether the tundra will melt and release enormous amounts. But methane does not stay in the atmosphere long, like CO2s. For the other greenhouse gases, there is no similar calculation as for the CO2s: If humans could eat less meat from cows, it would mean a great improvement, as more than a billion cows emit methane. Food from chicken should replace beef meat and burgers. The general formula reads:

(2) $d T=\lambda * d F$, Where ' $d T$ ' is the change in the Earth's average surface temperature, ' $\lambda$ ' is the climate sensitivity, usually with degrees Celsius per Watts per square meter $\left({ }^{\circ} \mathrm{C} /[\mathrm{W} / \mathrm{m} 2]\right)$, and ' $d F$ ' is the radiative forcing.

\section{The COP21 Approach: Policy Failures}

Once it was accepted by major groups that climate change would be very detrimental to social systems and the ecology, especially after Schneider's great effort, the UN started its machinery for finding policies that could stem global warming. The model emphasis of Kaya upon energy consumption and anthropogenic causes of climate change were endorsed. And the Stern focus upon combatting global warming as an externality implied the invention of policy tools (Stern, 2007, 2015)

The final result of the UN efforts was the making of the COP21 Agreement in Paris 2015, called a crowning achievement in the fight against these Stern external effects. The decisions, becoming Public International Law, included the following:

1) GOAL I: all countries must end $\mathrm{CO} 2$ increase by 2020; 


\section{Macrothink}

Journal of Public Administration and Governance

ISSN 2161-7104

2017, Vol. 7, No. 2

2) GOAL 2: all countries accept to reduce $\mathrm{CO} 2$ emissions by 2030 with some $40 \%$ of the 2005 level; this objective is open to various interpretations as different numbers figure often;

3) GOAL 3: all countries will decarbonize entirely by 2075.

Moreover, the COP21 Treaty outlines a number of mechanisms to make policy implementation credible, like 5 year oversight cycles and substantial money support for poor and developing nations - Stern' Super Fund.

Are the COP21 objectives implementable? This is the key question that confronts mankind in the $21^{\text {st }}$ century, as Schneider emphasized 1989. And the Kaya model pinpoints why implementation will be problematic, namely the links between emission - energy consumption and the GDP. Two figures may clarify the implications of Kaya's equations (Appendix I)

We show in Figure 1 that GDP increase with the augmentation of energy per capita. Decarbonisation is the promise to undo these dismal links by making GDP and energy consumption rely upon carbon neutral energy resources, like modern renewables and atomic energy.

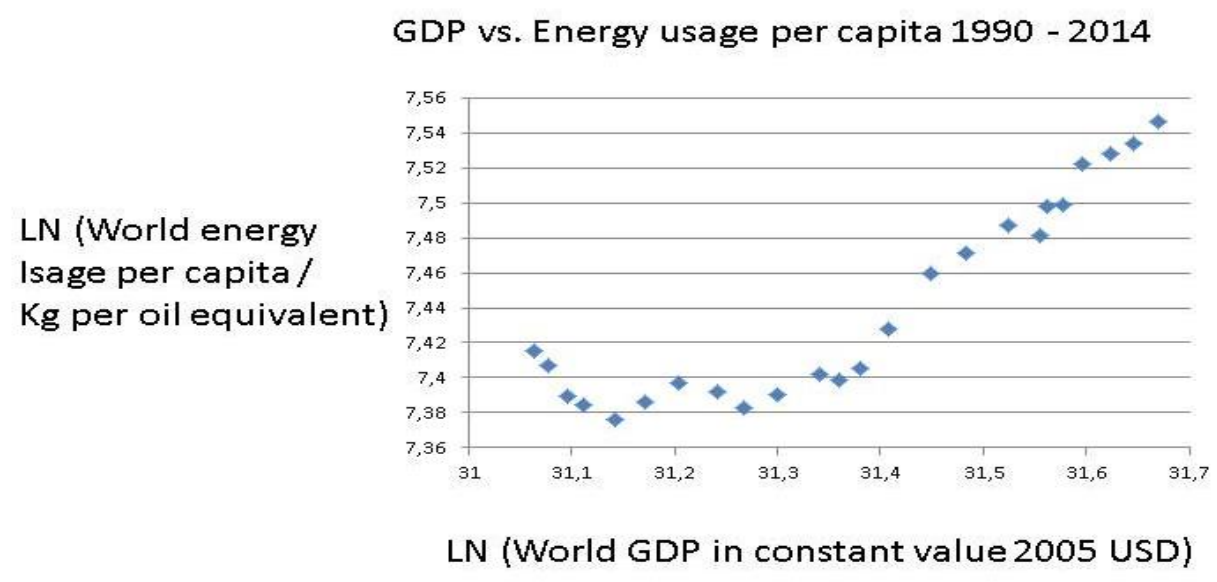

Figure 1. GDP against energy per person (all countries)

The implication of Figure 1 for the countries of the globe is that they need massive energy to keep their economies expanding.

Not only may all forms of energy be measured, but all these measures are translatable into each other - a major scientific achievement. One may employ some standard sources on energy consumption and what is immediately obvious is the huge numbers involved - see Table 1. 


\section{Macrothink}

Table 1. Energy consumption 2015 (Million Tons of oil equivalent)

\begin{tabular}{|l|l|l|}
\hline & Total & $\%$ \\
\hline Fossil fuels & 11306,4 & 86,0 \\
\hline Oil & 4331,3 & 32,9 \\
\hline Natural Gas & 3135,2 & 23,8 \\
\hline Coal & 3839,9 & 29,2 \\
\hline Renewables & 1257,8 & 9,6 \\
\hline Hydroelectric & 892,9 & 6,8 \\
\hline Others & 364,9 & 2,8 \\
\hline Nuclear power & 583,1 & 4,4 \\
\hline Total & 13147,3 & 100,0 \\
\hline
\end{tabular}

Source: BP Statistical Review of World Energy 2016

Examining Table 1, one understands the size of the task of decarbonisation. Complete decarbonisation would mean the elimination of the energy consumption of fossil fuels and traditional renewables. This is a herculean task, impossible simply. But the mix of energy usage will change during this century towards more of carbon neutral energy sources. Now, total energy consumed causes the total emissions of GHG: s from anthropogenic sources, which is driving climate change. Figure 2 shows how global GDP has expanded considerably the last 25 years with an enormous increase in total $\mathrm{CO} 2$ :s.

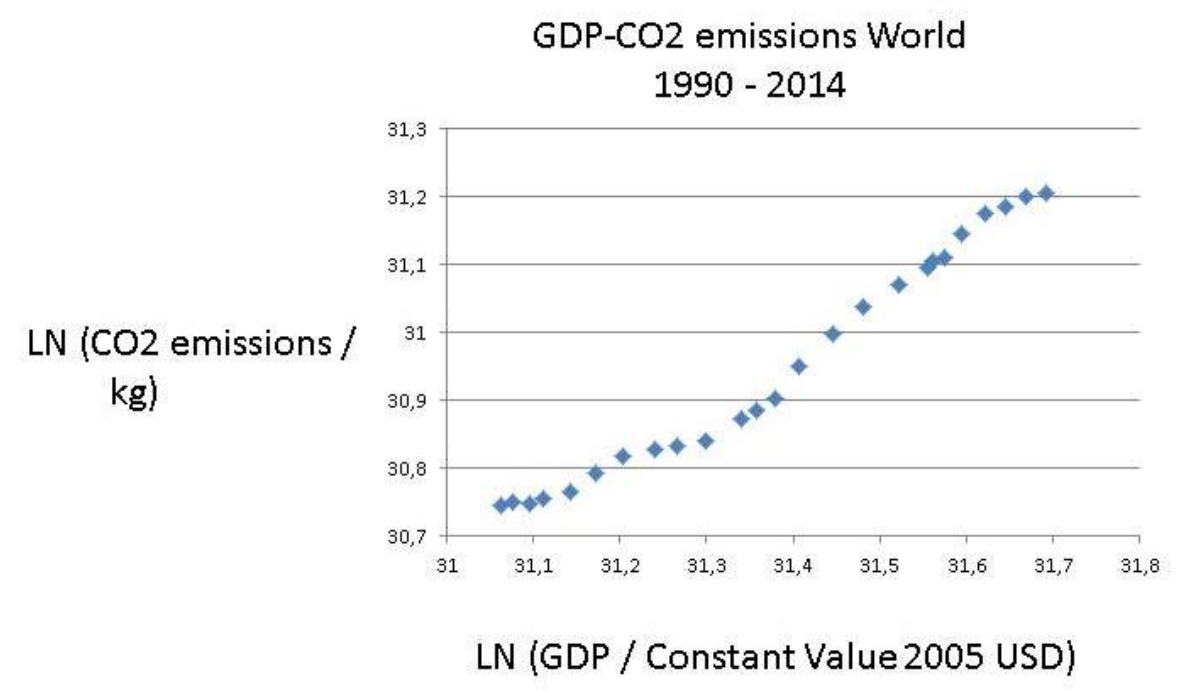

Figure 2. Global GDP-CO2 link: $y=0,80 x+5,96 ; \mathrm{R}^{2}=0,97(\mathrm{~N}=59)$

The findings in Figure 2 show that total GHG:s or CO2:s go with larger total GDP, i.e. GDP per person * population. To make the dilemma of energy versus emissions even worse, we showed in Figure 1 that GDP increase with the augmentation of energy per capita. This makes the turn to a sustainable economy suggested by Sachs in 2015 unlikely, as nations plan for much more energy in the coming decades.

Combining Figure 1 and 2, we understand the money involved in any decarbonisation plan. 


\section{Macrothink}

Journal of Public Administration and Governance

ISSN 2161-7104

2017, Vol. 7, No. 2

Countries will hesitate to comply with the COP21 objectives, at least not without pecuniary compensation.

The vast literature on policy implementation speaks of the probability of implementation failures. Let us exemplify what could happen when there is no international government with authority to direct and correct implementation. Here is a list of policy failures or implementation difficulties.

\section{RENEGING}

In creating a common pool regime, the principal challenge is to keep it together, as one or several parties to the agreement may defect. Actually, one big country has already defected on the COP21, namely Trump's USA.

\section{USA: Defection}

Energy consumption is almost as high in the US as in China, despite a much smaller population, meaning that per capita energy consumption is the highest in the world, outside of the Gulf States where Qatar is on top. Energy and affluence is basically the same, viz capacity to do work.

Figure 4 indicates that the upwards trend of energy use has recent stalled. This may be due to the financial recession starting in 2007-2008, but it may also be related to the ongoing energy transformation in the US, away from coal that delivered much of US energy consumption.

The plans for future energy needs in the US include a heavy augmentation, but one cannot tell whether it will come about from renewables or fossil fuels like fracking. The market for energy is somewhat bewildering in the country with the start of oil and natural gas exports again as well as the shut down of a few atomic power plants. Yet, fracking is not environmental friendly. Lots of solar plants are coming up, but their efficiency is low compared with nuclear plants.

Figure 4 shows that carbon emissions have peaked for the US.

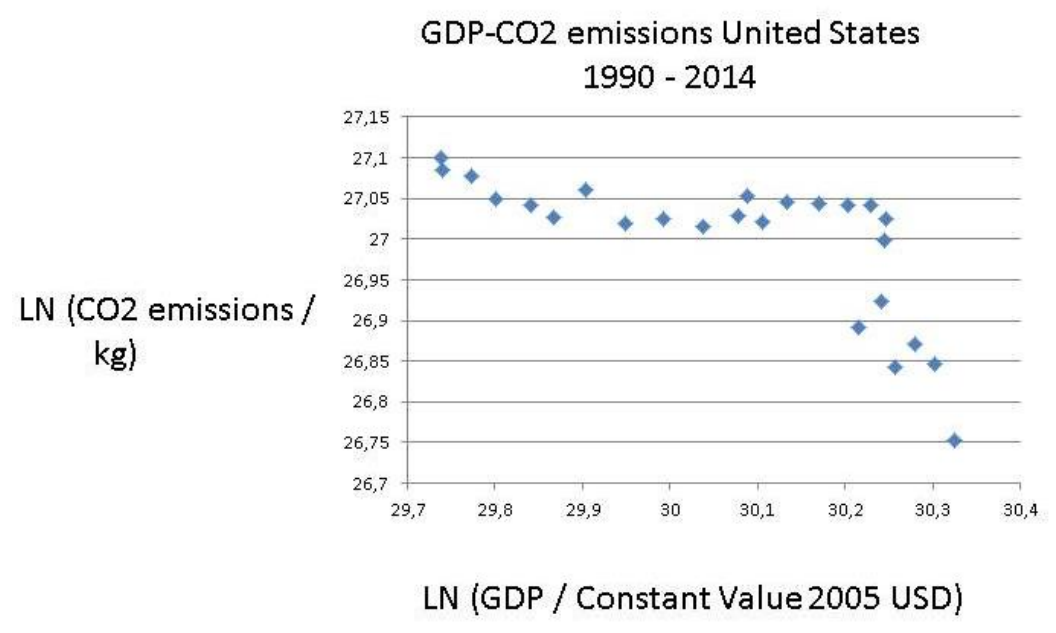

Figure 4. The US: $y=-0,32 x+36,7 ; R^{2}=0,49$ 


\section{Macrothink}

Journal of Public Administration and Governance

ISSN 2161-7104

2017, Vol. 7, No. 2

Recently, the level of $\mathrm{CO} 2$ emission has been reduced significantly in the US. It reflects partly the economic crisis that began 2007, but the entire energy pattern is undergoing change, from coal towards modern renewables. Yet, the US remains the second largest polluter in the world. This $\mathrm{CO} 2$ reduction reflects that the US can draw upon a mixed bag of energies, including nuclear and hydro power, with solar power expanding rapidly (Figure 5).

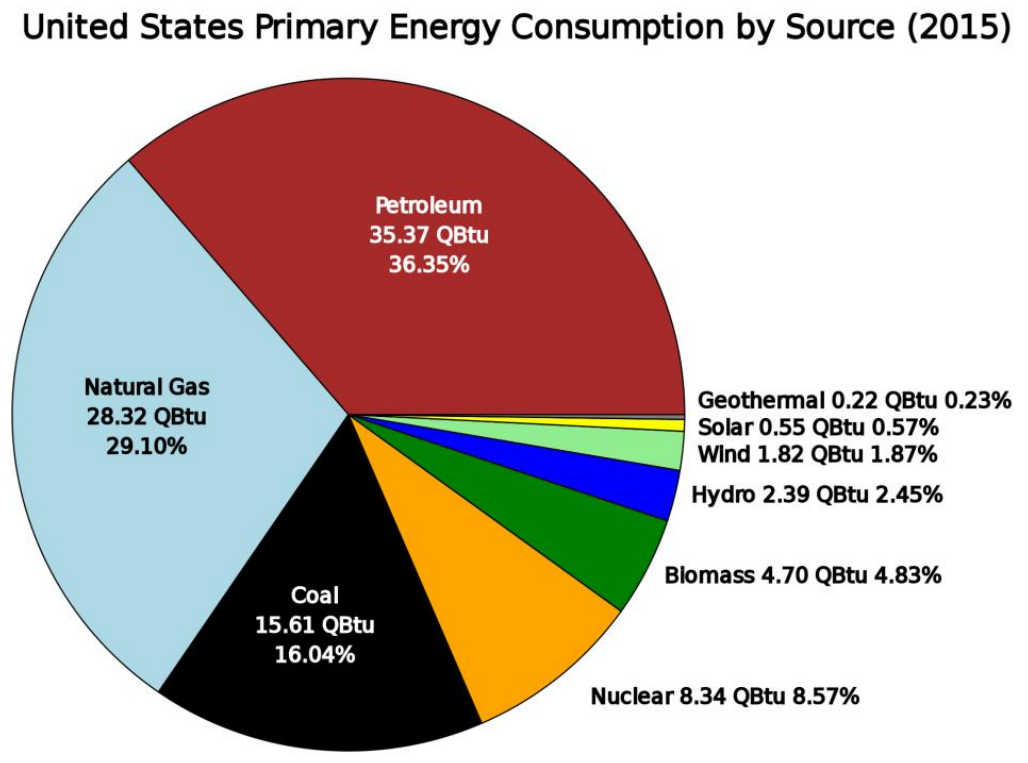

Figure 5. Energy mix in the US

The US is still heavily dependent upon fossil fuels, as some 80 per cent comes therefrom, the US facing a challenge of reaching GOAL II. What is changing is the shale rock innovation, as more and more of energy is produced within the US, allowing even for considerable export of petroleum. The shale oil and gas revolution may though not promote decarbonisation. Further reduction of $\mathrm{CO} 2$ :s may meet with firm resistance from the Republican House of Congress, which may oppose the COP21 Agreement, like president elect Trump. However, solar power should be attractive in many US states, both in micro use in households and large plant use.

Not only coal consumption is being decreased but also atomic power is cut back, as it cannot compete with energy from shale rock. Yet, when solar and wind power falters, natural gas enters the picture. Solar plants take enormous amounts of space. Energy policy-making is most active in Washington, involving a complex system of tax deductions and returns.

The advent of shale oil and gas has changed the entire energy markets, lowering the price of oil most substantially. This implies not only that there will be no Hubbert peak oil for the world, but also that switching to renewable energy source will be extremely expensive, relatively speaking compared with shale oil and gas. When petroleum is abundant, then investments in carbon neutral power sources may be non-lucrative and require massive state subsidies.

\section{Australia: Economic growth first}




\section{Macrothink}

Journal of Public Administration and Governance

ISSN 2161-7104 2017, Vol. 7, No. 2

Prime ministers in Canberra have said that Australia puts economic growth as the first priority. But Australia has always been the country of fossil fuels, exporting coal and iron in huge amounts. However, it has reached its $\mathrm{CO} 2$ peak recently (Figure 6).

GDP - CO2 for Australia 1990 - 2014

LN (CO2 Emissions / kg of oil equivalent)

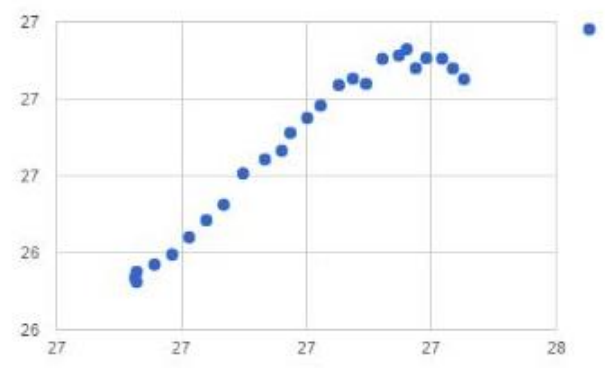

LN (GDP / Constant Value $2005 \$$ )

Figure 6. Australia's GDP-CO2 link

Australia has been extremely dependent upon fossil fuels, domestically and in exports in Asia. Cutting back its coal dependency will allow the country to halt its $\mathrm{CO} 2$ emissions, while moving to renewables. The fossil fuel dependency of Australia is simply stunning (Figure 7).

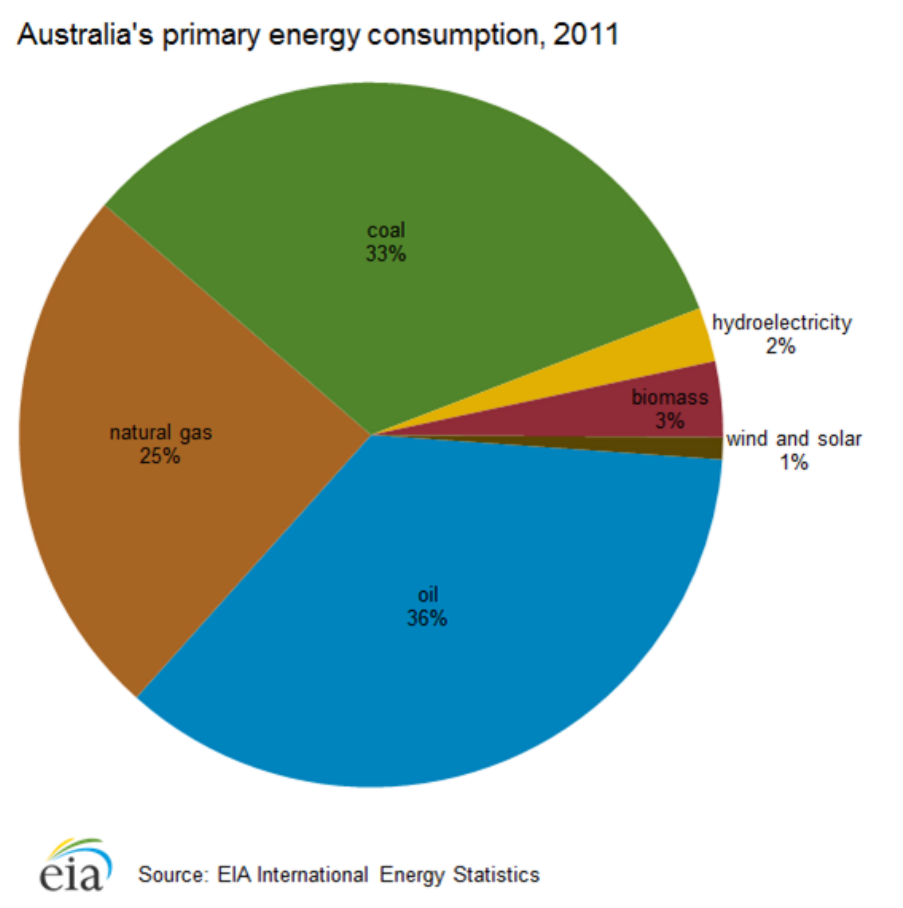

Figure 7. Energy mix in Australia

Australia has often been accused of fuelling climate change. These accusations appear to be vindicated in the Figure above that shows an extreme reliance upon fossil fuels. Add then all the export of raw materials: coal, iron, oil and gas! One prime minister of Australia has 
declared that the country will reduce $\mathrm{CO} 2$ :s only if economic growth is not hurt. It remains to be seen how Australia tackles Goal I and Goal II. Can the country really give up coal, domestically or in exports?

\section{Delaying}

\section{India: 300 million without electricity}

India is one of greatest polluters on the planet, and they are heading for the number 1 position, if the projection about population growth and economic development come true. The overall environment in South Asia is fragile by massive littering as well as recurrent droughts.

Energy consumption in India is planned to augment over the coming decade, as the ambition is to provide electricity to the whole population. Some 300 million people are today without electric power, and the population of India is growing fast. Mass povertyis the only outcome of this imbalance between total energy and total population, where India is heading for becoming the largest country in the world soon, population wise. Public intellectual and former minister Ramesh states that India has no alternative but to build more coal fired energy plants. Thus, we may expect that Figure 8 will show more of an upward trend in the decade to come, violating already Goal I.

GDP - Energy Consumption India 1990 - 2015

LN (Primary Energy

Consumption / kg

Oil equivalent)

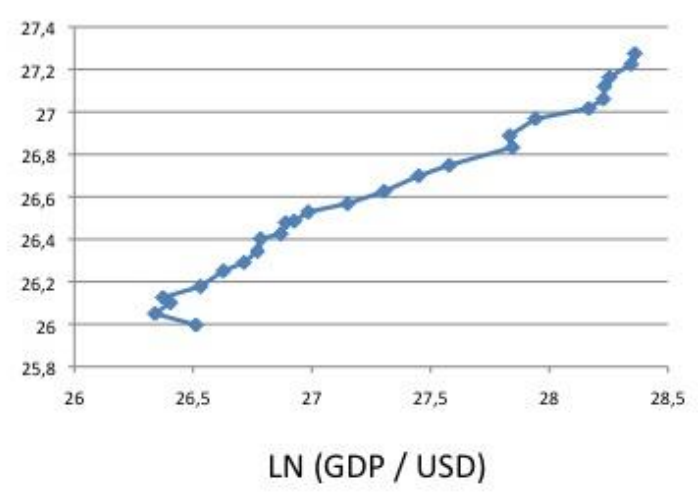

Figure 8. India's link GDP-energy: $\quad \mathrm{y}=0,55 \mathrm{x} ; \mathrm{R}^{2}=0,98$

Besides burning lots of fossil fuels, Indian housholds rely much upon wood coal in its various forms, such as charcoal, peat and dung. Wood coal is detrimental to people and the environment. As wood coal releases CO2:s, the use of biomass is typically defended by the argument that it also stores $\mathrm{CO} 2$, meaning that the use of biomass would be basically carbon neutral. However, this argument completely bypasses that wood coal in poor nations is conducive to deforestation and desertification, which is what happens on a large scale in India (Ramesh, 2015).

Figure 9 shows the constant increase in emissions. India will certainly appeal to the fairness problematic, namely per capita against aggregate emissions. India actually has one of the smallest numbers for energy per capita, although it produces much energy totally. The country is more negative than China to cut GHG emissions, as it is in an earlier stage of 


\section{Macrothink}

Journal of Public Administration and Governance

ISSN 2161-7104 2017, Vol. 7, No. 2

industrialization and urbanization, the "take-off" stage. Figure 9 shows also the close connection between carbon emissions and GDP for this giant nation.

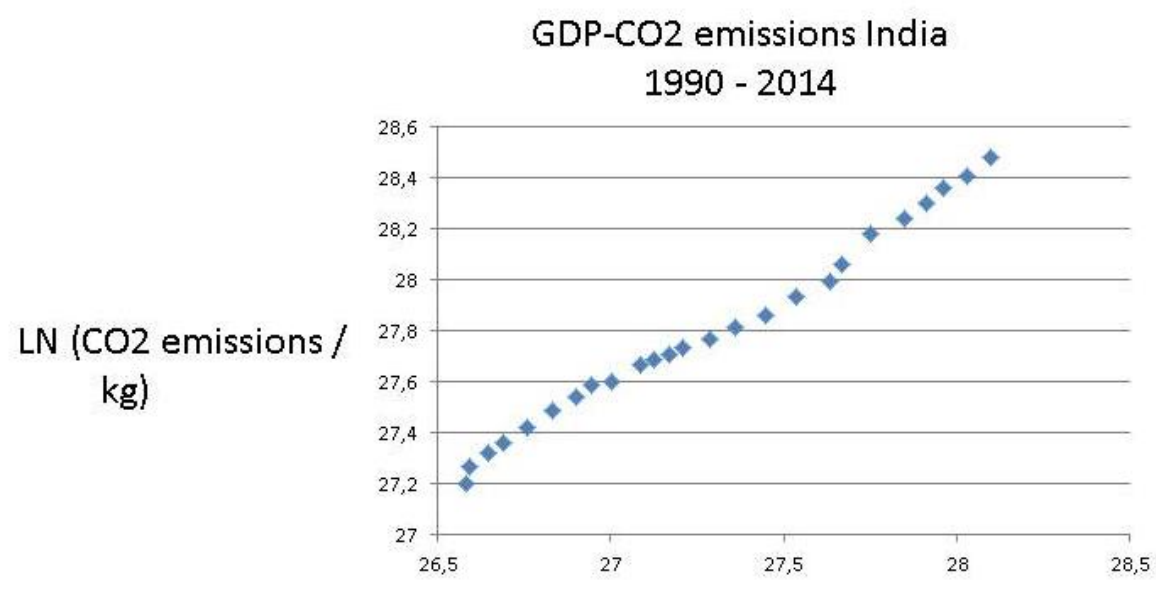

LN (GDP / Constant Value 2005 USD)

Figure 9. India: Link between GDP and CO2:s: $y=0,77 x+6,79 ; R^{2}=0,99$

India needs cheap energy for its industries, transportation and heating as well as electrification. From where will it come? India has water power and nuclear energy, but relies most upon coal, oil and gas as power source. It has strong ambitions for the future expansion of energy, but how is it to be generated, the world asks. In its energy mix traditional renewables - wood, charcoal and dung - play a bigger role than in for instance China. Figure 10 shows its present energy mix.

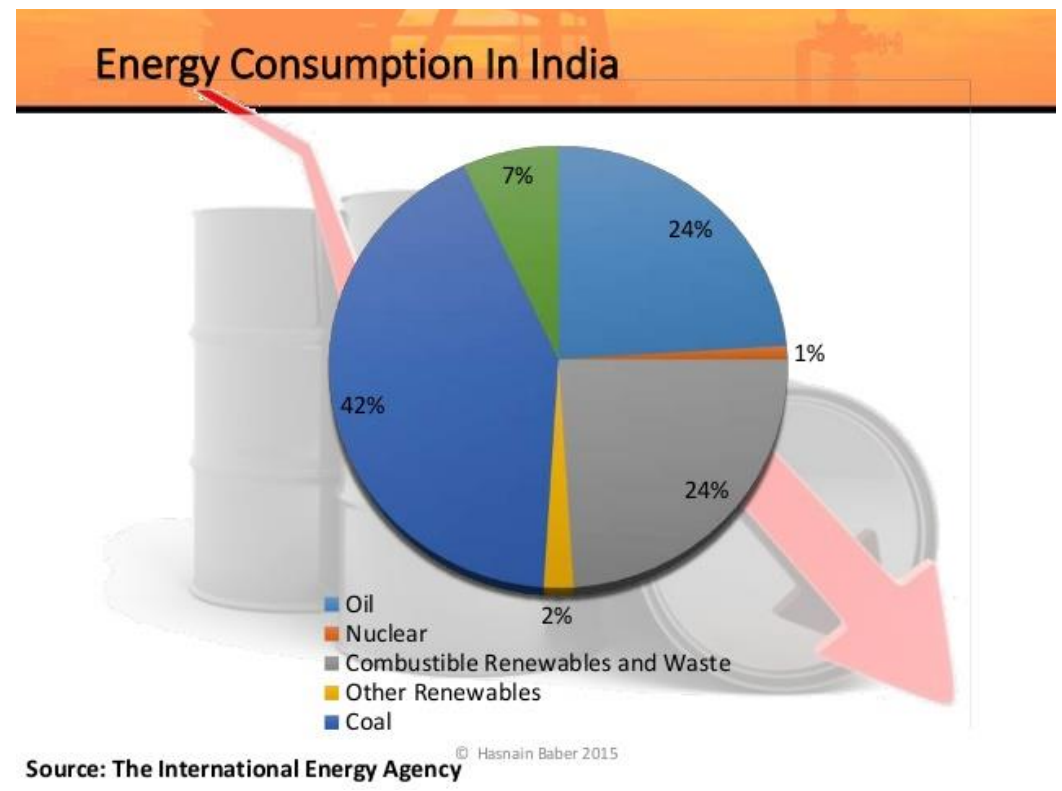

Figure 10. Energy mix in India 2014 


\section{Ml Macrothink}

Journal of Public Administration and Governance

ISSN 2161-7104

2017, Vol. 7, No. 2

India is heavily dependent upon stone and wood coal as well as oil and natural gas. To change this pattern towards modern renewables will take a long time and require massive financial assistance from the Super Fund. Since India is a federal state, the management tasks will be complex and involve conflicts between the powerful states. India cannot comply with the COP21 objectives. Energy transformation is slow and requires capital as well as policy-making. India's need for energy is overwhelming.

\section{Japan: Nuclear option?}

Japan has a huge energy consumption, but it hovers from year to year, reflecting not only the stagnation of the economy but also the occurrence of natural disasters (Figure 11). Japan has been forced to increase fossil fuel imports to compensate for the close down of several nuclear plant.

It is hardly a daring guess that the nuclear plant disaster in Japan together with the decision to close most such power plants has further increased emissions, as the country now relies upon fossil fuels much more. Governments make plans, but they may not hold for unforeseen developments. Japan is today more dependent upon fossil fuels than earlier due to the debacle with its nuclear energy program. Is really solar, wind or atomic power realistic in Japan on the scale needed for massive decarbonisation? When forced, governments renege, i.e. they will turn back to the fossil fuels, as for them economic growth trumps the environment. After all, nations are brutally egoistic, at least according to standard teachings in international relations.

$\mathrm{LN}\left(\mathrm{GHG} / \mathrm{Kg} \mathrm{CO}_{2}\right.$ eq.)

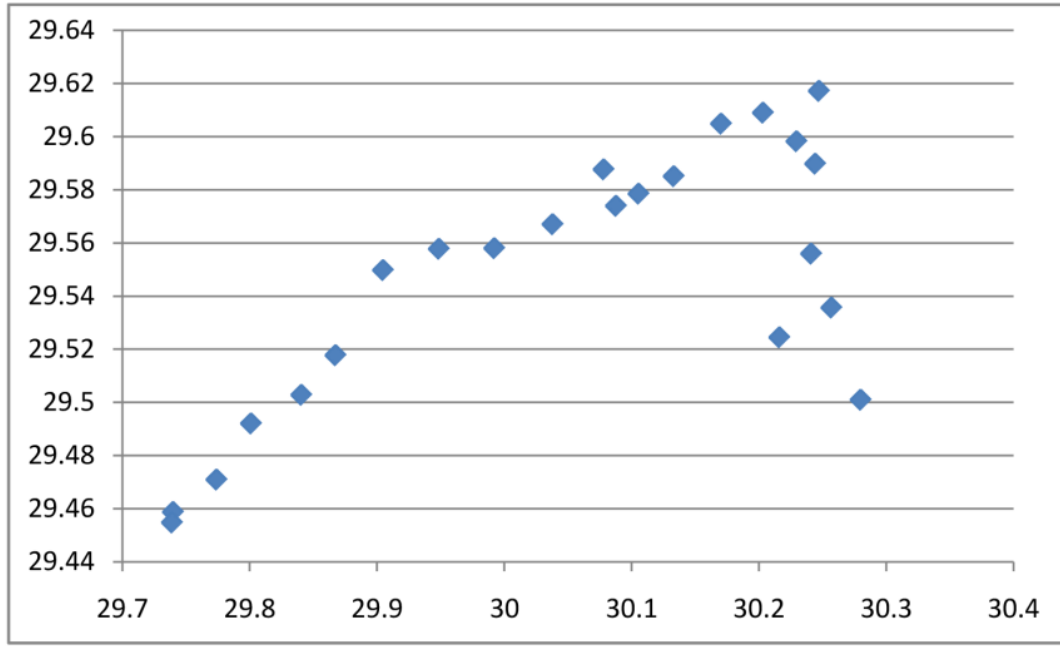

LN (GDP/Constant Value 2005 USD)

Figure 11. Japan's GDP-CO2 link: $y=0.2648 x ; R^{2}=0.194$

With an extremely high standard of living, based on the consumption of very much electricity, Japan will have to increase its energy use. And it cannot rely upon domestic sources or renewables. Figure 12 rightly projects increased use of fossil fuels in Japan, which goes against the COP21 goals. 


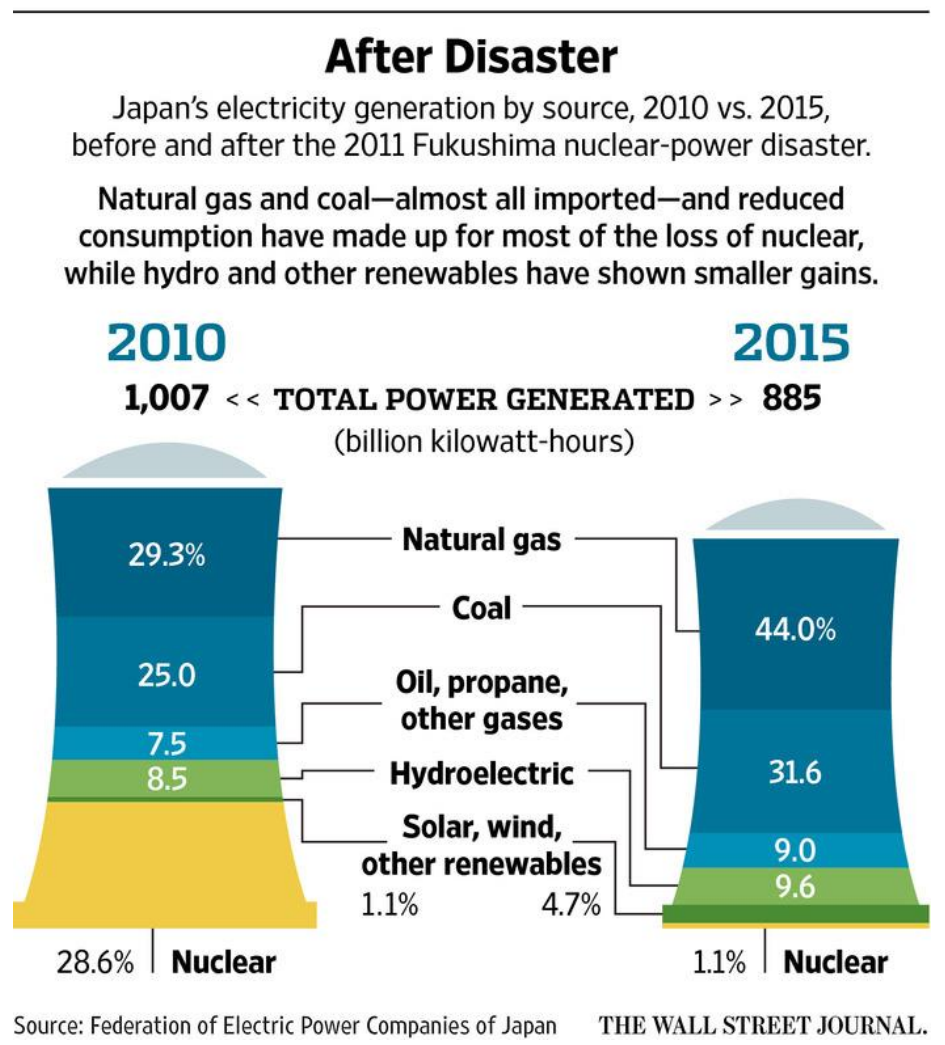

Figure 12. Energy min in Japan

\section{Oversight Difficulty}

The COP21 project promises an evaluation mechanism, but this performance of decarbonisation is hard to analyse for countries where there are both subtractions and addition of $\mathrm{CO} 2 \mathrm{~s}$.

\section{China: Reducing and expanding $\mathrm{CO} 2 \mathrm{~s}$}

It holds true that China is taking several steps in the direction of decarbonisation, especially reducing the consumption of coal. Thus, atomic power stations are built and massive investments in solar and wind power occur. Yet, at the same time, China is pushing ahead with its socio-economic development towards modernisation and post-modernity, employing market incenyives. New and bigger cars are sold, new autostradas are built, new airports are put up and urban developments are spawling with skyscrapers - all taking lots of cement. What does it add up to? Reply: need of energy.

In a uniquely rapid economic development over a few decades, China has moved from the Third World to the First World with stunningly new giant cities cropping up and modern infrastructure being introduced to its old cities. With economic growth rates hovering around 10 per cent, China is no longer a poor nation. The trick has been to employ market incentives (Barry, 1982: Hayek, 1991), resorting to a massive mobilisation of energy, partly imported from Australia among others. Figure 13 has the colossal step forward towards a mature economy. 
LN (Primary Energy

Consumption / kg

Oil equivalent)

\section{GDP - Energy Consumption China 1990 - 2015}

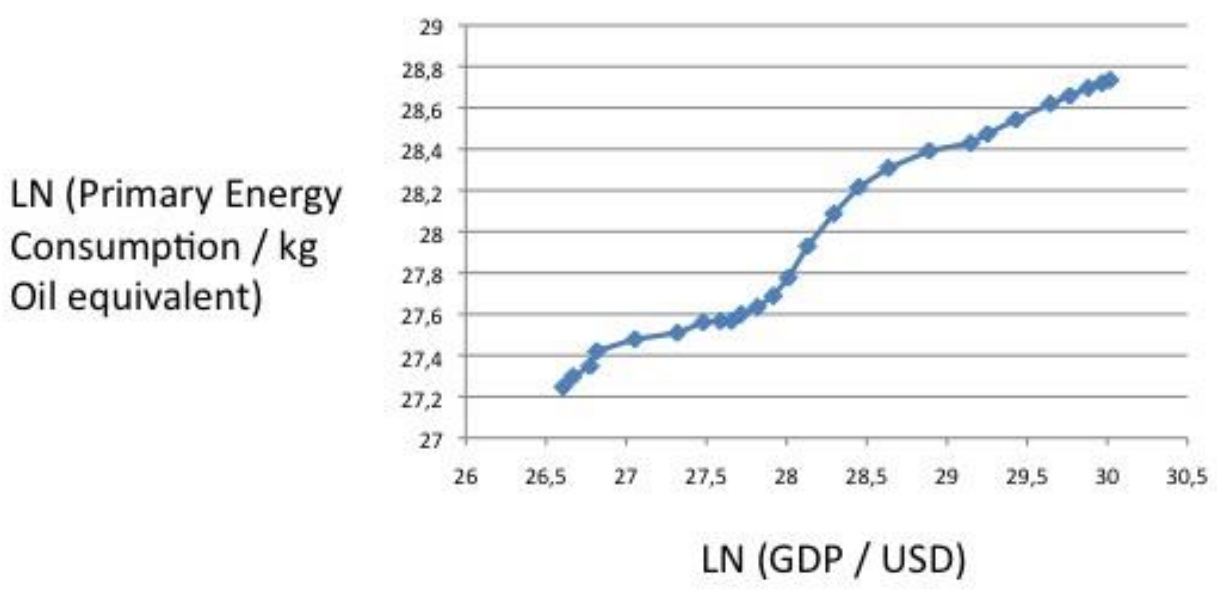

Figure 13. Energy and GDP in China: $y=0,46 x ; R^{2}=0,97$

China has multiplied its energy usage several times over, drawing upon internal and external resources, mainly fossil fuels. It used to rely upon internal oil and natural gas, but now it is a major global importer. Its exports are gigantic to the US and the EU, and it is tying other Third World countries into patterns of cooperation, or some would say dominance economically, like African nations and Pakistan. However, the price is not only overall environmental deterioration but also the world's largest $\mathrm{CO} 2$ emissions (Figure 14).

A few nations do not depend upon any foreign assistance, because they are highly developed technologically and can draw upon own substantial financial resources. One may find that the emissions of GHG:s follows economic development closely in many countries. The basic explanation is population growth and GDP growth - more people and higher life style demands. Take the case of China, whose $\mathrm{CO} 2$ emissions are the largest in the world, totally speaking. China was a Third World country up until yesterday.

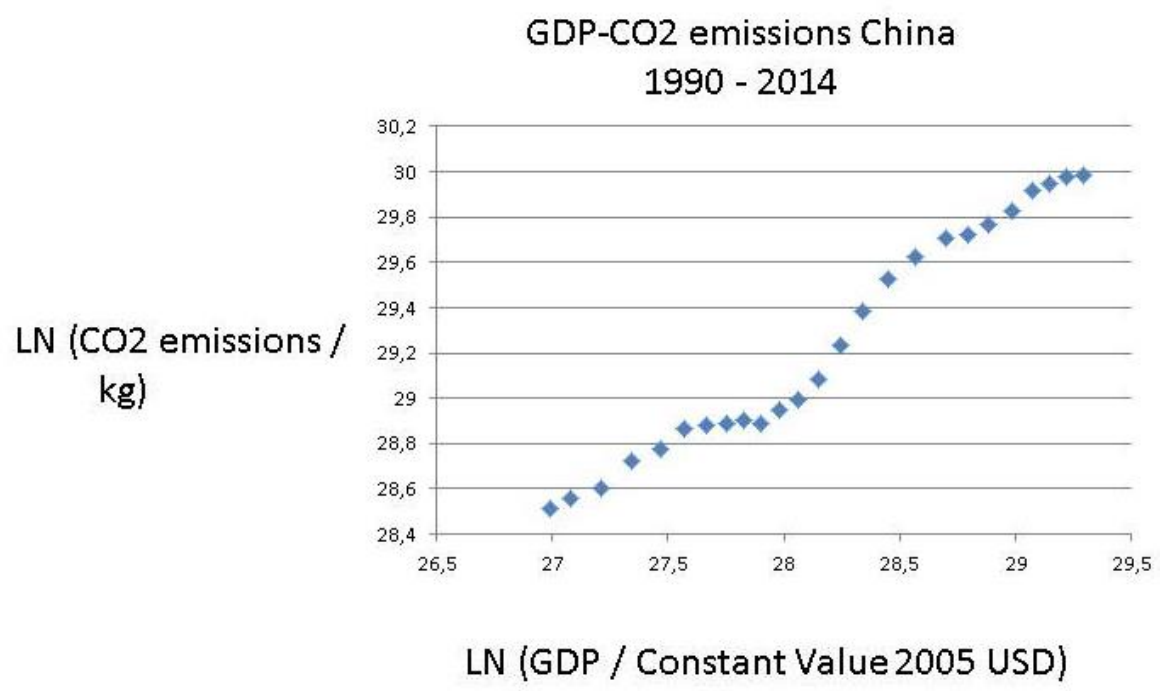

Figure 14. CHINA: GDP-CO2 link: $y=0,70 x ; R^{2}=0,97$ 


\section{Macrothink}

Journal of Public Administration and Governance

ISSN 2161-7104

2017, Vol. 7, No. 2

The sharp increase in CO2:s in China reflects not only the immensely rapid industrialization and urbanization of the last 30 years, but also its problematic energy mix with around 90 per cent of energy consumption coming from fossil fuels.

The energy consumption mix in China is different from that of India, as wood coal is not used much. Figure 15 has the energy mix.

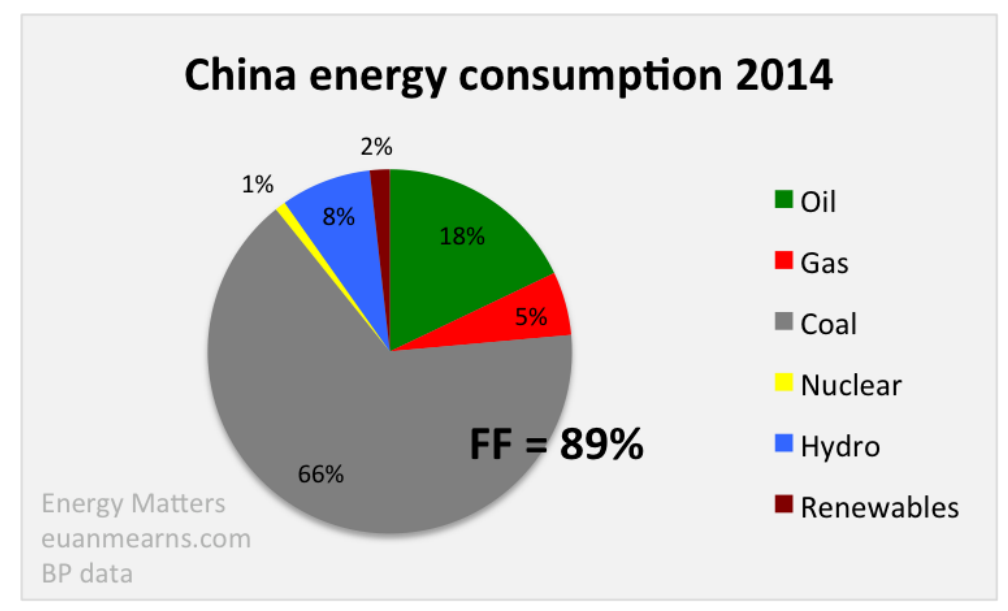

Figure 15. China's energy mix

It may be underlines that these data in Figure 15 underestimate the share of atomic and renewable power, but it provides an indication of how much China must change to comply with the COP21 goals. Water power is fully utilised, meaning that atomic, solar and wind power must be the future energy sources. In any case, China is not on route to achieve the COP21 goals.

\section{RUSSIA: Numbers correct?}

Concerning emissions, Russia comes very high, reflecting noy only its past but also its economy geared towards natural resources. In terms of energy, Russia is on an upwards trend, although it use more in the 1990s before the "dirty" industries were dismantlled. Figure 16 has the erratic GDP-energy link for this country.

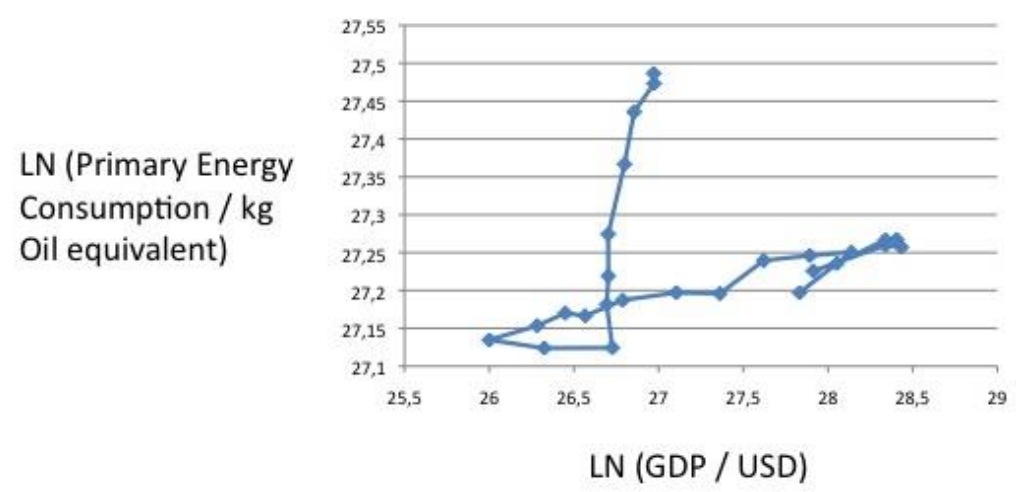

Figure 16. Russia' link GDP-CO2: $y=0,024 x ; R^{2}=0,036$ 


\section{Macrothink}

Journal of Public Administration and Governance

ISSN 2161-7104

2017, Vol. 7, No. 2

The statistics for Russia is erratic, but recently the trend is up. The country could never fulfill the three decarbonisation goals above. It runs on fossil fuels to 90 per cent. Russia has accepted that its hope for a major industrialization failed, concentrating its ambitions on the hope of being a global resources based economy. Energy wise, Russia is a fossil fuel country that when faced with the implications of decarbonisation a la $\mathrm{CO} 21$ will renege. Its global power ambitions can only be promoted by the employment of its fossil fuels. When challenged in the future, it falls back on its energy rich economy. The emissions curve shows the changes in energy consumption.

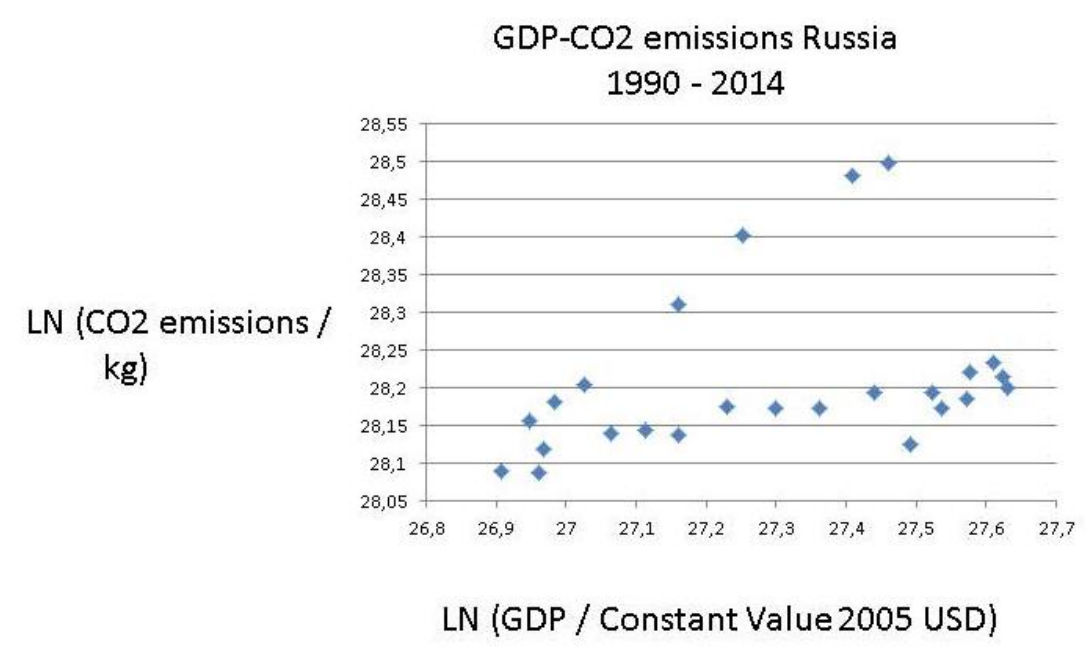

Figure 17. Russia: $\quad \mathrm{y}=0,14 \mathrm{x}+24,3 ; \mathrm{R}^{2}=0,11$

We find a sharp reduction in $\mathrm{CO} 2$ :s for Russia, which is a major polluter. It reflects the de-industrialisation of the Soviet Union. No countries treated their environments as badly as the Communist regimes. But Figure 17 also shows that emissions are no longer falling.

\section{Funding Quarrels}

One would expect to find huge $\mathrm{CO} 2$ emissions in this large emerging economy with lots of oil production. Countries like the Gulf States have massive CO2:s because they drill and refine oil and natutal gas. For Mexico holds the following situation (Figure 18).

\section{Mexico: Who pays?}

GDP - CO2 for Mexico $1990-2014$

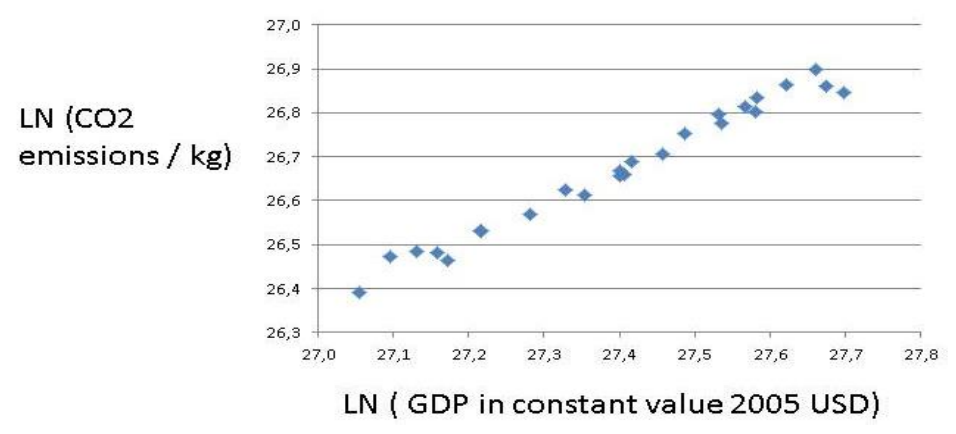

Figure 18. GDP-CO2 in Mexico: $y=0,77 x ; R^{2}=0,98$ 


\section{Macrothink}

Journal of Public Administration and Governance

ISSN 2161-7104 2017, Vol. 7, No. 2

The close link between economic development and $\mathrm{CO} 2$ is discernable in the data, but the emissions growth seems to stagnate in the last years. This is of course a promising sign, whether it is the start of a COP21 inspired 40\% reduction in CO2:s remains to be seen. I doubt so, but let us enquire into the energy mix of this huge country that is of enormous economic importance to both North and South America.

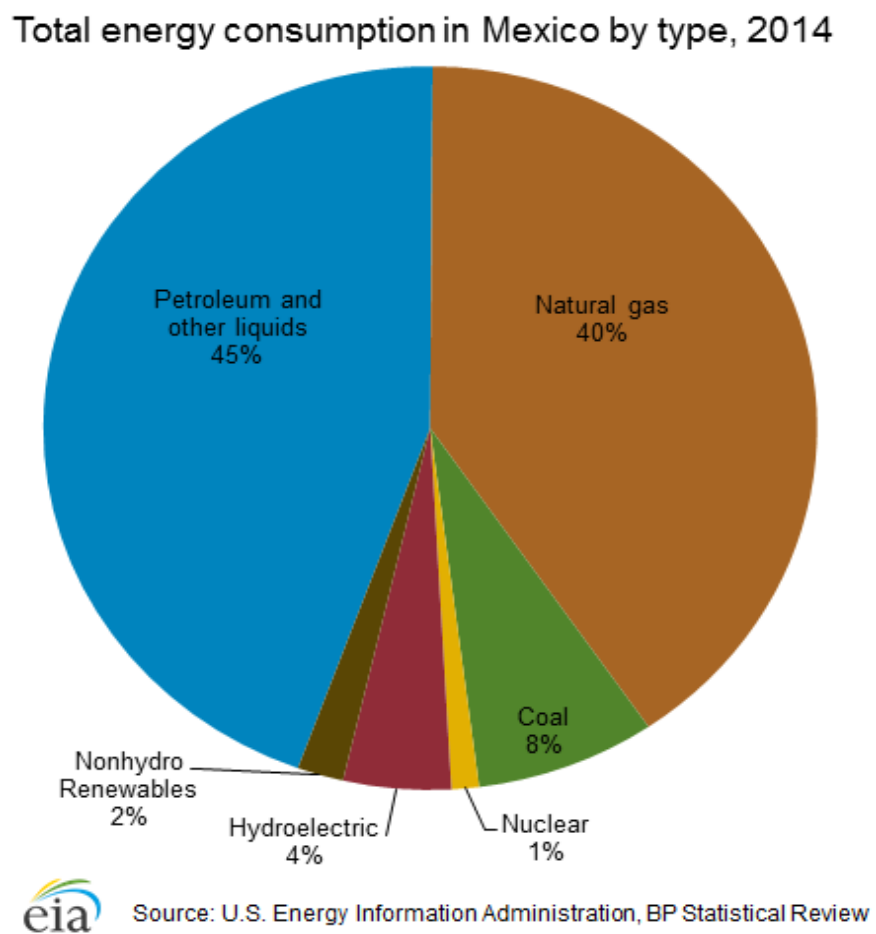

Figure 19. Energy mix for Mexico

Few countries are so deependent upon fossil fuels as Mexico (Figure 19). One find the same patter with the Gulf States. The Mexican government must start now to reduce this dependency, by for instance eliminating coal and bringing down petreoleum, instead betting upon solar, wind and nuclear power. Mexico will face severe difficulties with the $40 \%$ reduction target in COP21. It has a fast growing population with many in poverty and an expanding industry sucking electricity. Can economic growth and decarbonisation go together here?

\section{Iran: Who pays?}

Countries may rely upon petroleum and gas mainly - see Iran (Figure 20). CO2 emissions have generally followed economic development in this giant country, although there seems to be a planning out recently, perhaps due to the international sanctions against its economy. 
GDP vs. CO2 emissions Iran 1990-2014

$\mathrm{LN}$

(CO2 emissions

$/ \mathrm{kg}$ )

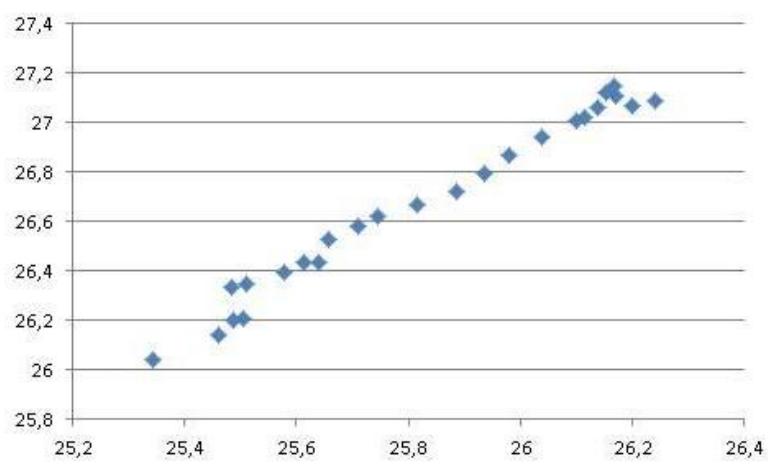

LN (GDP / (Constant Value 2005 USD))

Figure 20. Iran: GDP-CO2 link $\left(\mathrm{y}=1,2229 \mathrm{x}-4,91 ; \mathrm{R}^{2}=0,98\right)$

Iran is together with Russia and Qatar the largest owner of natural gas deposits. But despite using coal in very small amounts, its $\mathrm{CO} 2$ emissions are high. Natural gas pollutes less than oil and coal, but if released unburned it is very dangerous as a greenhouse gas. Iran relies upon its enormous resources of gas and oil (Figure 21).

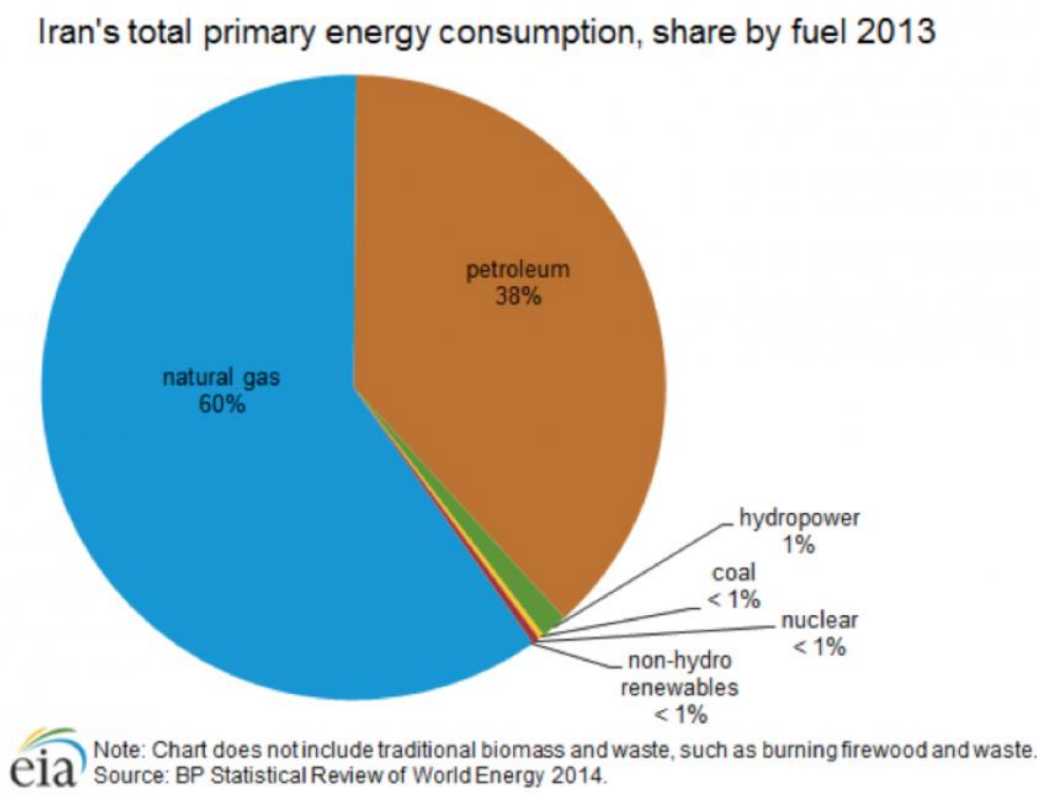

Figure 21. Iran: Energy mix

Iran needs foreign exchange to pay for all its imports of goods and services. Using nuclear power at home and exporting more oil and gas would no doubt be profitable for the country. And it would also help Iran with the COP21 goals achievement.

\section{Kazakhstan: Trusted?}

Whether modern renewables like solar energy can function in a harshly winterish climate is debated. Thus, a country may ask why bet on solar power when we have massive amounts of 


\section{Macrothink}

fossil fuel power"

Here, we have a nation very much occupied with the catch-up strategy. It wants to copy the Asian miracles, moving to affluence in a few decades, using its immense fossil energy resources (Figure 22).

Kazakhstan's energy consumption by fuel, 2012

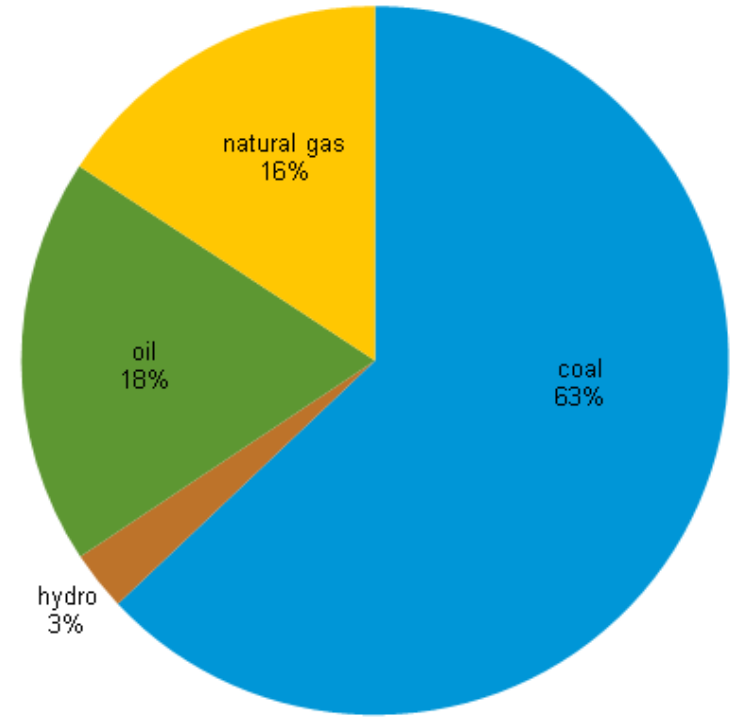

eia Source: U.S. Energy Information Administration

Figure 22. Energy mix in Kazakhstan

However, this energy consumption leads to enormous emissions (Figure 23). The stunning economic development, including the great project of a modern Silk Road from China to Germany through Kazakhstan implies that the CO21 goals cannot be accomplished here. Catch-up and huge infrastructure trumps climate change. Countries with no hydro power often display increasing trends for emissions. Consider this oil and gas rich country in Asia.

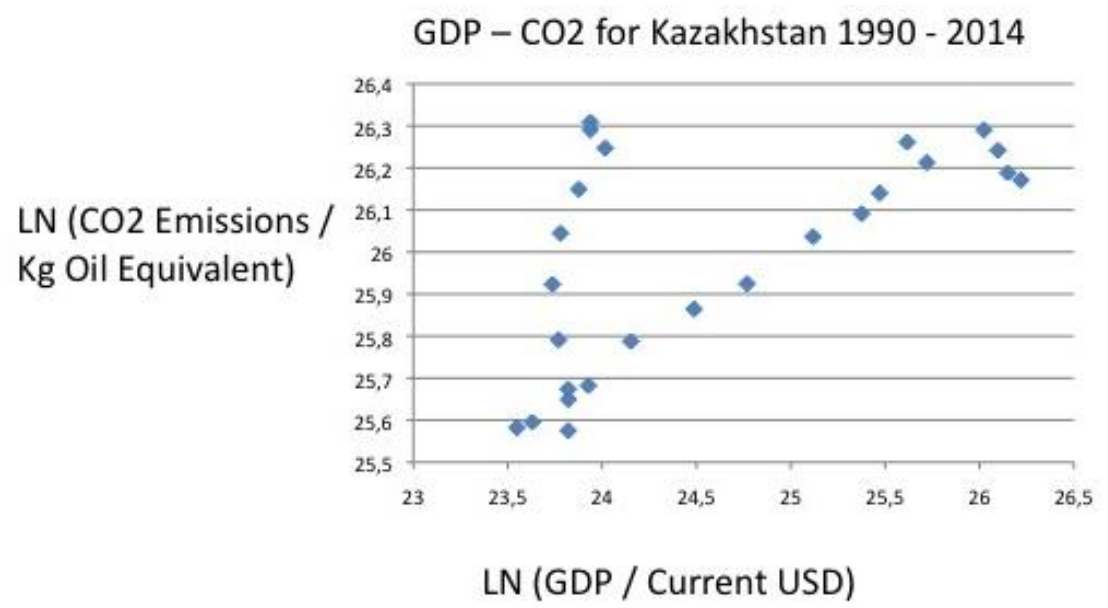

Figure 23. Kazahkstan's link $\left(\mathrm{y}=0,1671 ; \mathrm{R}^{2}=0,38206\right)$ 
Kazahkstan employs its vast fossil fuel resources for energy consumpton besides exporting a lost.

\section{State Weakness}

Implementation, argued Aaron Wildavsky, is problematic. Can it be achieved in countries with weak public administration?

Brazil: "Brazil is a country of the future... and always will be.".

Brazil has for a long time been in the forefront of environmental concerns. On the one hand, it has paved the way for an alternative to the oil dominance in transportation by developing a domestic biomass industry on large scale. The ethanol is derived from immense sugar plantations and it has reduced oil dependency, especially when international petrol prices have skyrocketed. On the other, there is the constant worry that Brazilian governments are ineffective in protecting the lungs of the Planet Earth, the giant rain forest in the Amazonas.

First, we may establish that Brazil produces much $\mathrm{CO} 2$ :s, and this as a function its economic development (Figure 24).

GDP - CO2 for Brazil $1990-2014$

$\mathrm{LN}$ (CO2

emissions / kg)

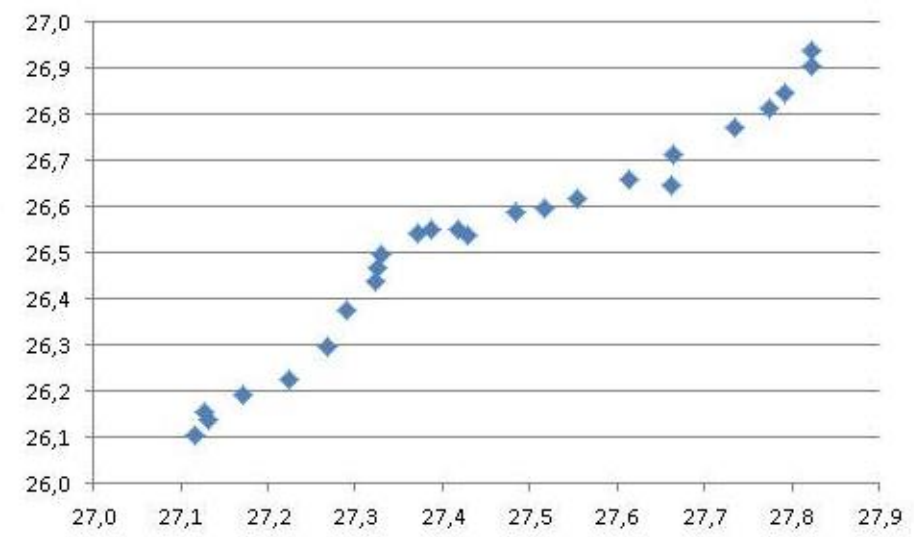

LN (GDP in constant value 2005 USD)

Figure 24. GDP-CO2 in Brazil: $y=1,02 x ; R^{2}=0,95$

The trend in Brazil for CO2:s is like in Argentina up and up. When the burning of the rain forest is added, then Brazil is one of the largest $\mathrm{CO} 2$ emitter in the world. The country may reply that its energy mix and its huge forests decrease $\mathrm{CO} 2$ :s by consuming $\mathrm{CO} 2$ (Figure 25). 


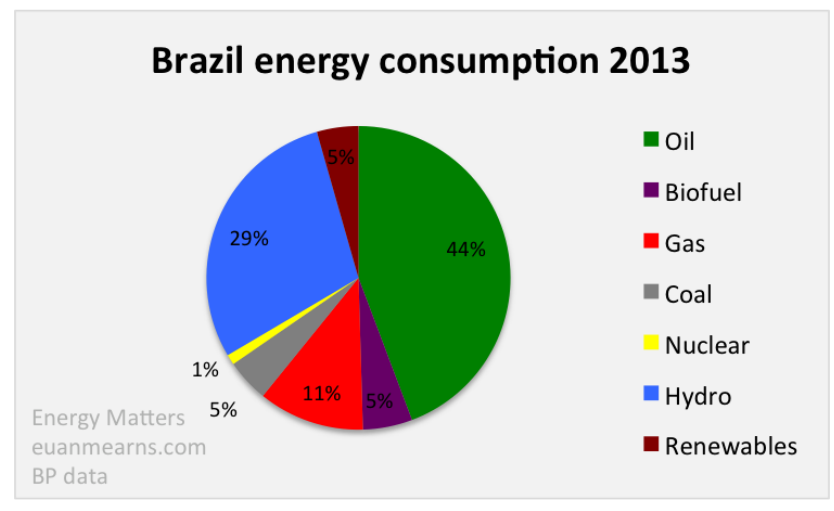

Figure 25. Energy mix of Brazil

Source: http://euanmearns.com/brazil-samba-energy/

Hydroelectric power is massive in Brazil and capacity has grown steadily since 1965. However, hydro production has been down owing to late and light rains. Brazil is one of the few countries in the world where liquid biofuel production is significant: ethanol. Gas production in Brazil is significant, but Brazil has very little of coal production. In 2006, the discovery of vast oil resources in the sub-salt strata of the Santos Basin promised petroleum bonanza, but deep water and sub-salt setting has posed technical challenges and high costs. Brazil has a few nuclear reactors, but nuclear provides only $1 \%$ of primary energy.

One can hardly say that it will easy for Brazil to live up to its COP21 commitments, despite its comparatively low dependence upon fossil fuels. Its large hydro power supply is vulnerable to draught, as rivers dry up. And then one must add the political difficulties in managing the oil and gas reserves properly in giant enterprise Petrobas. The huge Mato Grosso could be used for renewable energy generation, wind and solar power. The plans for massive hydro power in the Amazons will destroy this rainforest.

\section{Indonesia: No ecology control at all}

Indonesia has rapidly moved up as a major consumer of energy in the early 21 rst decade., refelcting growimh political stability and a strong effort to catch-up with the other Asian miracles. It has definitely passed its "take-off" stage, but interestingly its enormous consumption of energy has not been accompanied by high economic growth in most recent years (Figure 26).

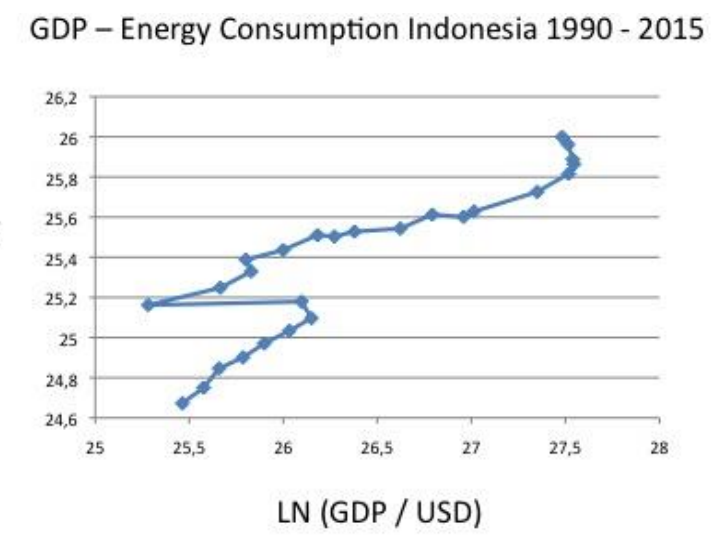




\section{Macrothink}

Journal of Public Administration and Governance

Figure 26. Indonesia: $\quad \mathrm{y}=0,46 \mathrm{x} ; \mathrm{R}^{2}=0,79$

The inward and upward sloping curve for Indonesia must be of concern to the elite in the country, because Indonesia has become a major contributor to $\mathrm{CO} 2$ emissions. If economic growth stalls due to inflation, then how to defend the enormous emissions?

The bad $\mathrm{CO} 2$ emissions stem partly from the cutting and burning of rain forests and adjacent land on Kalimantan and Sumatra, which the government is to weak to control. The illegal fires affect other neighbouring countries but little is done to stop them. The search for more land for agriculture, especially soya planations, drives the externality. Emissions even outpace energy consumption. These rain forests are bound to disappear, as the Indonesian state does not have the capacity or even willingness to police these huge areas.

One may guess correctly that countries that try hard to "catch-up" will have increasing emissions. This was true of India. Let us look at three more examples, like e.g. giant Indonesia - now the fourth largest emitter of GHG:s in the world (Figure 27).

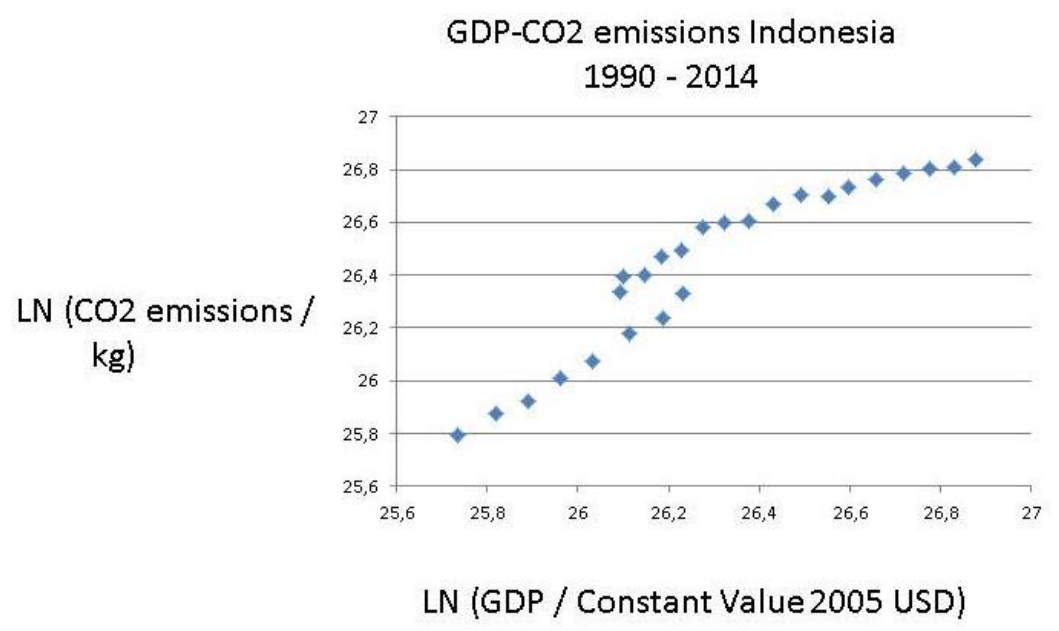

Figure 27. Indonesia: GDP-CO2 link: $y=0,95 x+1,58 ; R^{2}=0,89$

Indonesia is a coming giant, both economically and sadly in terms of pollution. Figure 27 reminds of the upward trend for China and India. However, matters are even worse for Indonesia, as the burning of the rain forest on Kalimantan and Sumatra augments the GHG emissions very much. Only 4 per cent comes from hydro power with 70 per cent from fossil fuels and the remaining 27 per cent from biomass, which alas also pollutes (Figure 28). 
Figure 1. Indonesia total primary energy consumption, 2013

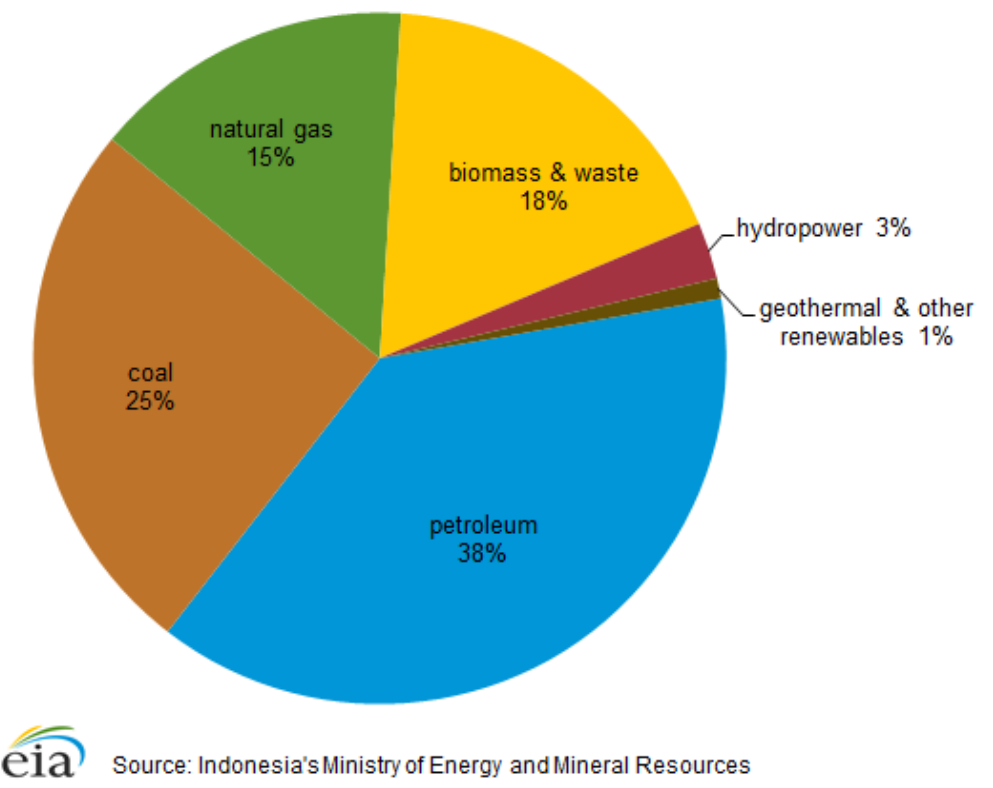

Figure 28. Indonesia's energy mix

The reliance on fossil fuels and wood coal is too heavy in Indonesia in order to fulfil the COP21 objectives.

\section{Transaction Costs}

Decarbonisation requires massive new investments. Many countries are in such economic troubles that they just cannot make them. Either they have to renege or they must be assisted by some kind of Super Fund. For some countries, the COP21 goals are critical. They stand to lose land mass and risks over-heating.

\section{Pakistan and Bangladesh: Victims of global warming}

The same upward trend for emissions holds for another major developing country with huge population, namely Pakistan (Figure 29).

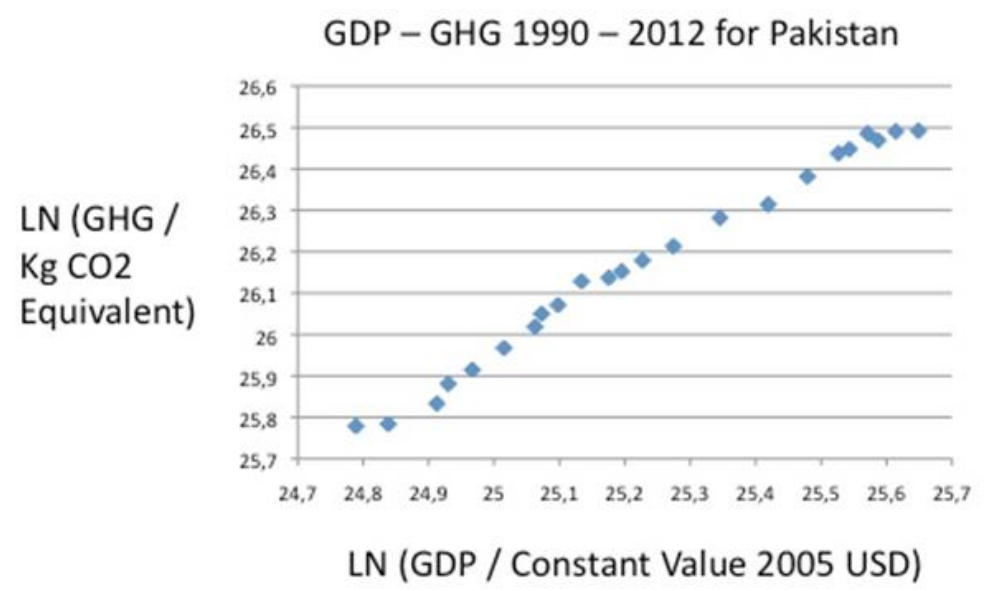

Figure 29. PAKISTAN: LN (GHG / Kg CO2 eq and LN (GDP / Constant Value 2005 USD) 


\section{Macrothink}

Journal of Public Administration and Governance

ISSN 2161-7104

2017, Vol. 7, No. 2

The amount of GHG emissions is rather large for Pakistan, viewed as aggregate. Pakistan is mainly reliant upon fossil fuels (Figure 30).

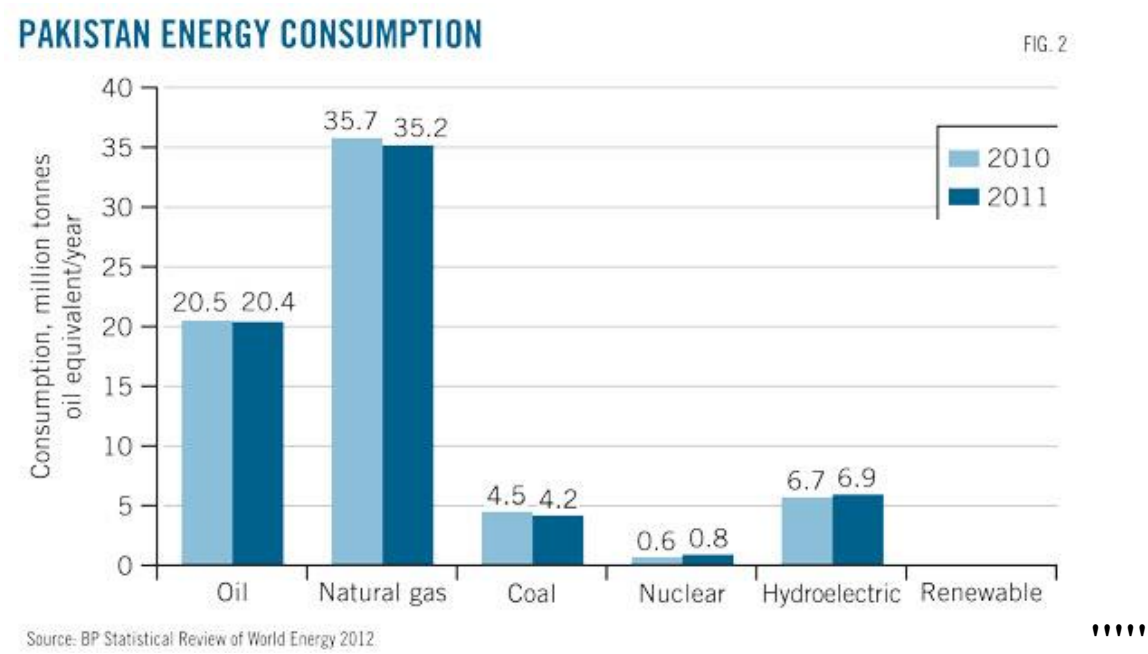

Figure 30. Energy mix in Pakistan

But Pakistan employs a considerable portion of hydropower - 13 per cent - and a minor portion of nuclear power, which is a positive.

Moving on to another giant nation in South Asia, Bangladesh, we find an entirely different set of conditions for implementing COP21. In Bangladesh like in all South Asian countries, the GHC:s or CO2:s follows economic development closely. Yet energy consumption in this very poor nation is based on a different energy mix, compared with for instance India. Figure 31 pins down the large role of traditional renewables like wood, charcoal and dung as well as the heavy contribution of oil and gas. Bangladesh needs external support for developing modern renewables, like solar, wind and geo-thermal power sources.

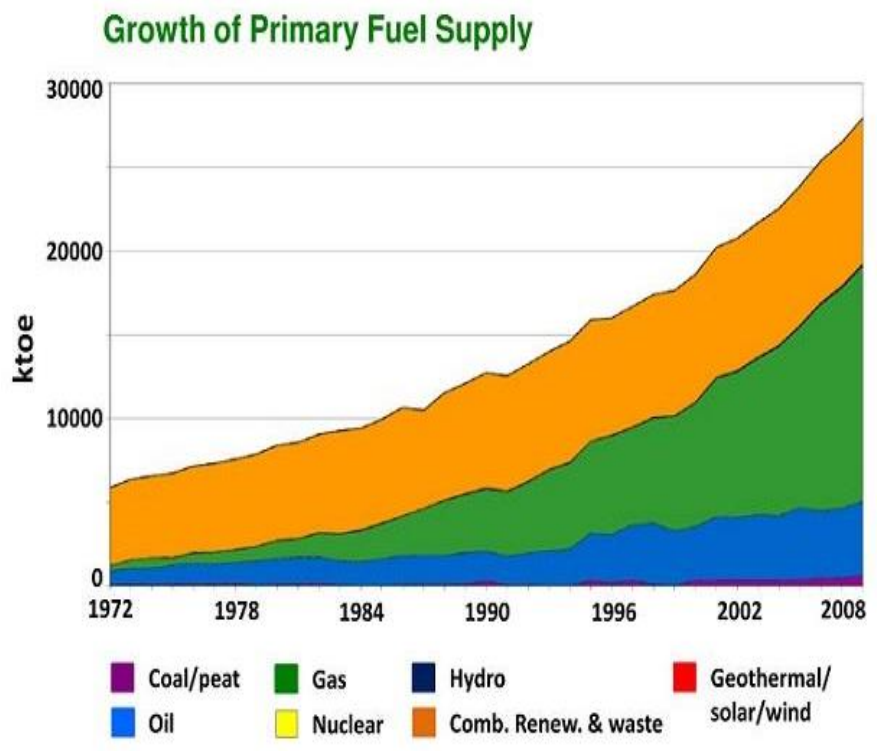

Figure 31. Bangladesh: energy mix

Source: Energy Scenario in Bangladesh from 1972-2008 (Orange: Biomass, Green: Gas, 
Blue: Oil)

I believe most countries "taking-off" in Rostow's (1960) terminologywill rely much upon fossil fuels, like the examples above. It can be pointed out that one finds no example of declining GDG-CO2(GHG) links in Latin American nations, nor in Africa or Asia, meaning that COP21 management will struggle to get GOAL I implement. But it is not difficult to identify countries can will need much assistance from the Super Fund: Egypt, South Africa, Nigeria, Peru, Venezuela, Argentina, Brazil, etc.

\section{Sri Lanka: Fragility of ecology}

When examining small but populous Sri Lanka, one sees again the strong connection between GDP and CO2: s-see Figure 32. It seems that the CO2: s was halted in their expansion for some time, but now they increase again.

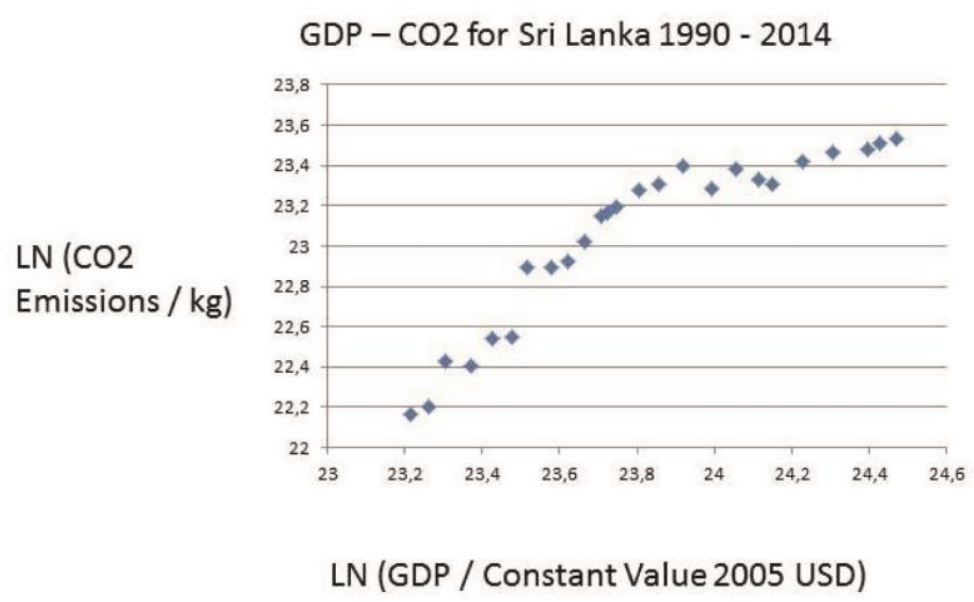

Figure 32. Sri Lanka: GDP-CO2: $\left(y=1,03 x, R^{2}=0,84\right)$

In this island state, the dominant energy source is traditional renewables, which leads to deforestation and $\mathrm{CO} 2$ emissions on a large scale (Figure 33). It has been argued that the forest will grow up again, eating the carbon emissions. But it is mainly wishful thinking, as climate change and draughts make forest rehabilitation difficult.

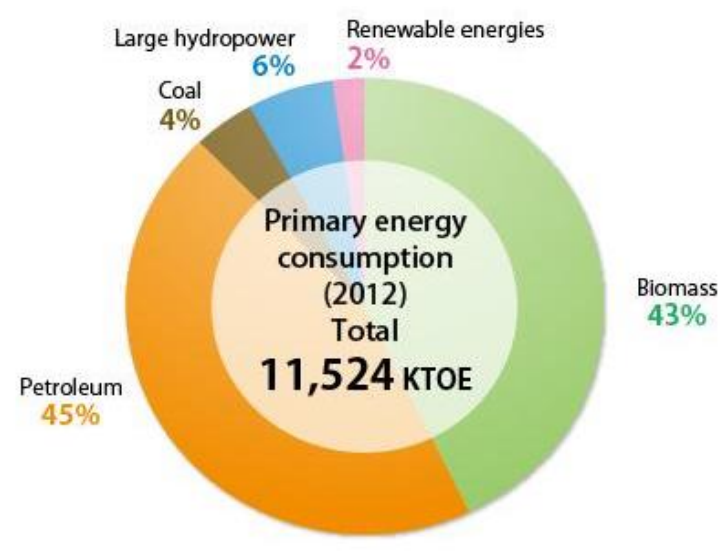

Figure 33. Sri Lanka’s energy consumption 


\section{Macrothink}

Journal of Public Administration and Governance

ISSN 2161-7104

2017, Vol. 7, No. 2

Source: Primary energy consumption in Sri Lanka (2012); http://www.info.energy.gov.lk/

For the poor nations in Asia with huge population holds that they cannot by themselves accomplish the objectives of COP21: Goal I: reverse current CO2 trend, Goal II: reduce by 40 percent the CO2: s by 2030 and Goal III: full decarbonisation by 2075. As a matter of fact, they will need massive financial assistance from the Super Fund, which has still not been founded.

Yet, this requires that the $\mathrm{COP} 21$ or $\mathrm{CO} 22$ sets up a management structure to assist these countries involving project evaluation, policy execution and implementation, control of financial flows and outcome assessment — a gigantic task with many pitfalls involved.

\section{Egypt: Solar plants and terrorism?}

Dismally poor Egypt that has only natural gas assets in large quatity. The emission trend is clear. It has a huge population with high unemployment and mass poverty besides a certain level of political instability, resulting from religious conflicts. But surely it has electricity from its giant Assuam dam and the Nile? No, it does not count for very much, where most people live in the Nile delta (Figure 34).

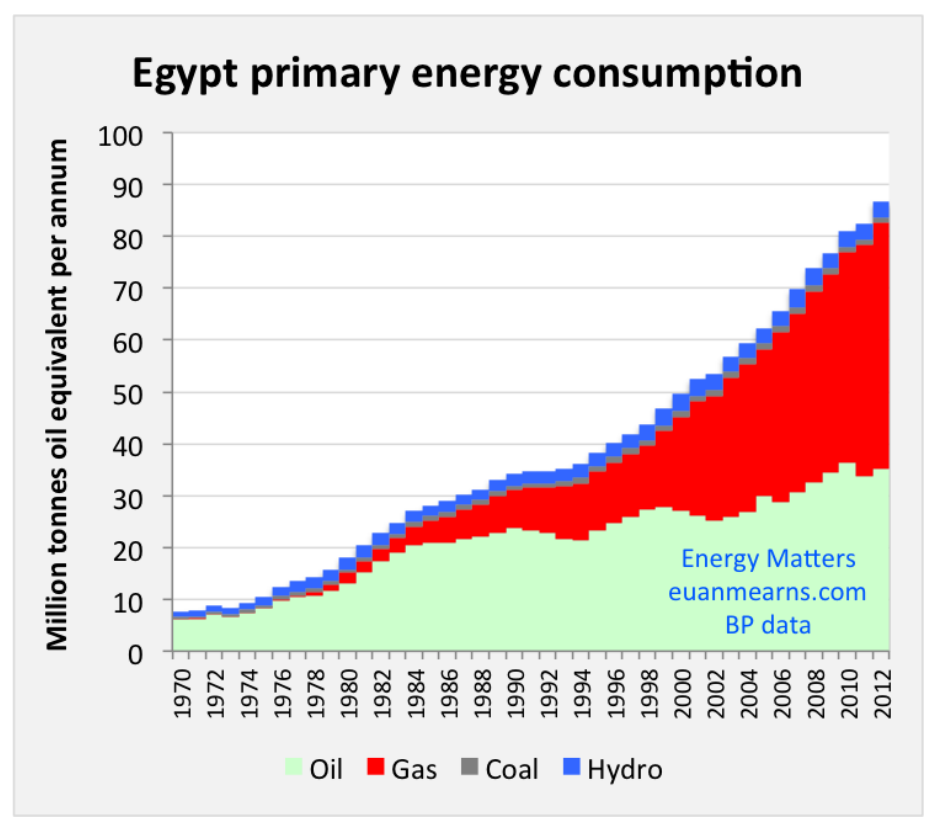

Figure 34. Egypt's eergy mix

The share of hydro power is stunning low for a country with one of largets rivers in the world. Actuallu, the water of the Nile is the source of interstate confrontation between Egypt, Sudan and Ethiopia.

As Egypt relies upon fossil fuels, it has massive $\mathrm{CO} 2$ emissions, the trend of which follows its GDP (Figure 35). It has petrol but not enough for its own consumption. But it exports natural gas. 


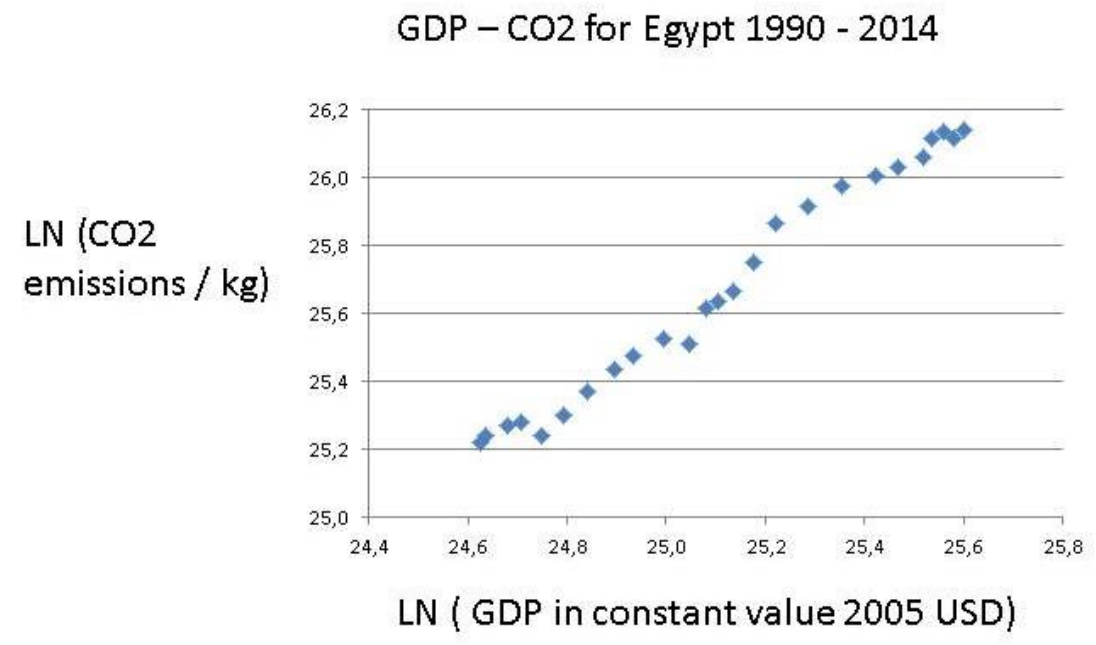

Figure 35. GDP-CO2 for Egypt: $y=1,02 x ; R^{2}=0,99$

It will be very difficult for Egypt to make the COP21 transformation, at least without massive external support. But where to build huge solar power plants in a country with terrorism, threat or actual? And how to finance massive energy transformation, if the promise of a Super Fund is reneged upon?

\section{What Is Involved in Renewables?}

A general claim in the climate change debate is that renewables should be preferred over non-renewables. Yet, this statement must be strictly modified, as there are two fundamentally different renewables:

- Traditional renewables: wood, charcoal and dung. They are not carbon neutral. On the contrary, employing these renewables results in severe pollution, not only outside but also inside a household;

- New renewables: solar, wind, geo-thermal and wave energy that are indeed carbon neutral, at least at the stage of functioning.

In the literature on $\mathrm{CO} 2$, it is not often pointed out what large role traditional renewables play in poor countries on the African and Indian continent. Wood coal is harmful to human health and polluted more than stone coal. Charcoal for instance stimulates deforestation and even forest theft.

\section{Congo, Nigeria and Ethiopia}

In the poor African countries with about half the population in agriculture and small villages, traditional renewables constitute the major source of energy. 


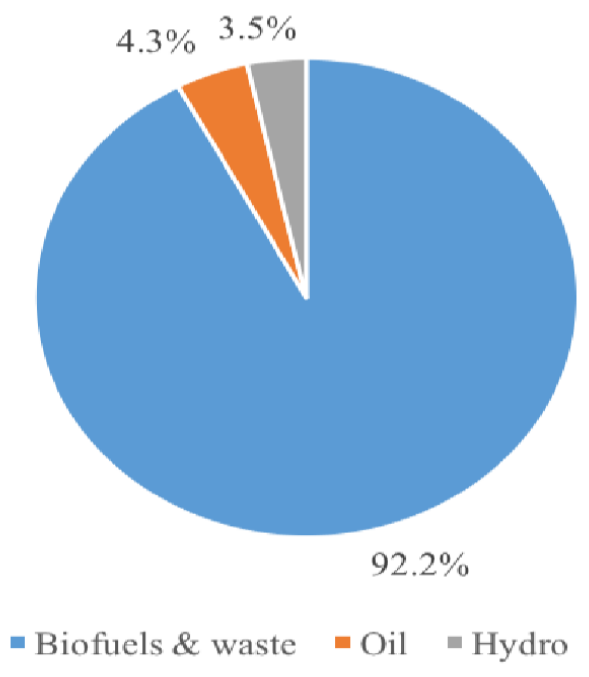

Figure 36. DR CONGO: energy consumption

Source: Democratic Republic of Congo - Energy Outlook, Kungliga Tekniska Hoegskolan

One notes how little of hydro power has been turned into electricity in Congo, but economic development and political instability, civil war and anarchy do not go together normally. At the same, one may argue that an extensive build-up of hydro power stations would pose a severe challenge to the fragile environment in the centre of Africa. Congo can now move directly to modern renewables like solar power.

Figure 1. Nigeria's total primary energy consumption, 2012

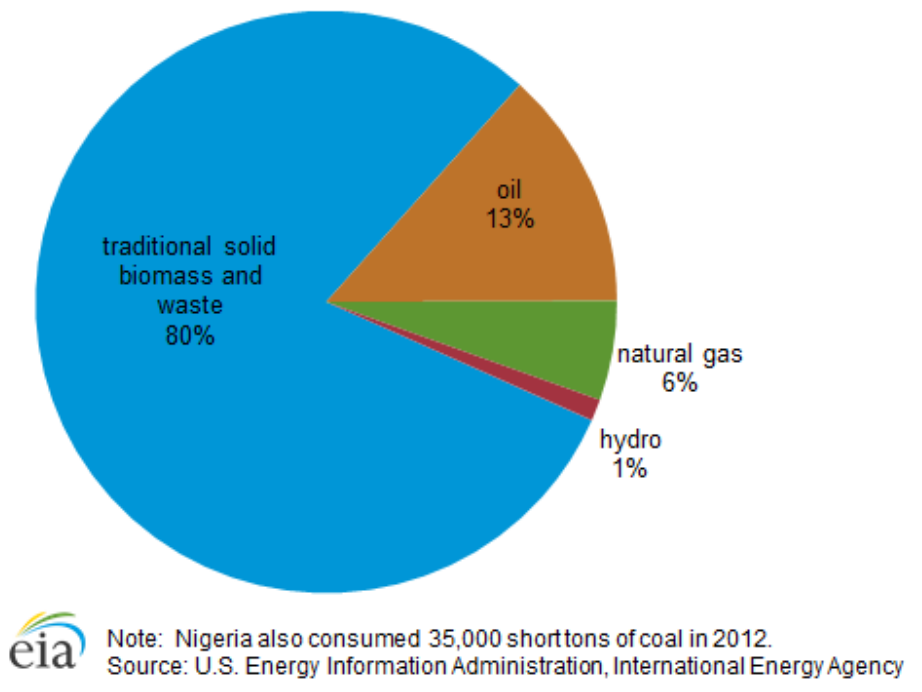

Figure 37. Nigeria's energy mix

Nigeria would have to diminish the use of traditional renewables in order to meet the COP21 goals. The very same policy recommendation applies to two countries in the Nile valley, namely Sudan and Ethiopia - extremely poor countries relying mainly upon traditional renewables. 


\section{Macrothink}

Journal of Public Administration and Governance

ISSN 2161-7104

2017, Vol. 7, No. 2

Surely, both Ethiopia and Sudan would want to utilise the great Nile River for their electricity consumption. However, Egypt wants to have a SAY over the energy planning of these two countries up the river. Thus, far many rounds of negotiations have resulted in the construction of only a few power plants, a few in Sudan (Merowe Dam, etc.) and one another huge in Ethiopia - Grand Ethiopian Renaissance Dam. The problem is the common pool of the Nile, where one country, Egypt, may find that the water level has shrunk too much for its own needs, electricity or irrigation. Actually, the risk of draughts is a real one for all countries trying to exploit the Nile. Sudan is dismally poor with deep-seated internal conflicts ethnically. How to move to large solar panel plants in a country with so much political instability resulting huge numbers of death from domestic violence? The reliance upon traditional renewables is so high in neighbouring Ethiopia that electrification must be very difficult to accomplish over the large land area. Figure 38 displays a unique predicament.

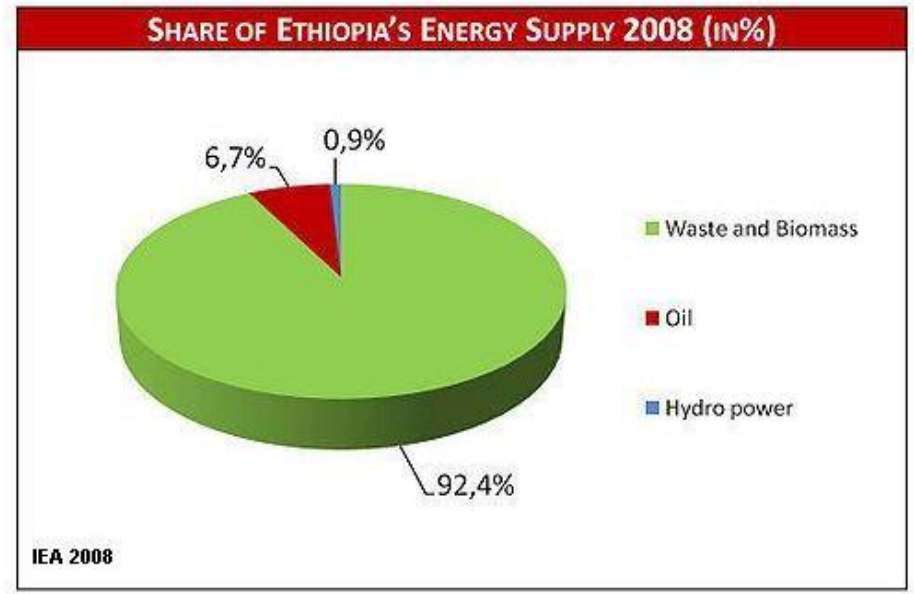

Figure 38. ETHIOPIA: Energy mix

Are there any advantages with such a skewed energy mix? No, because even mainly rural Ethiopia works with lots of CO2: - see Figure 39.

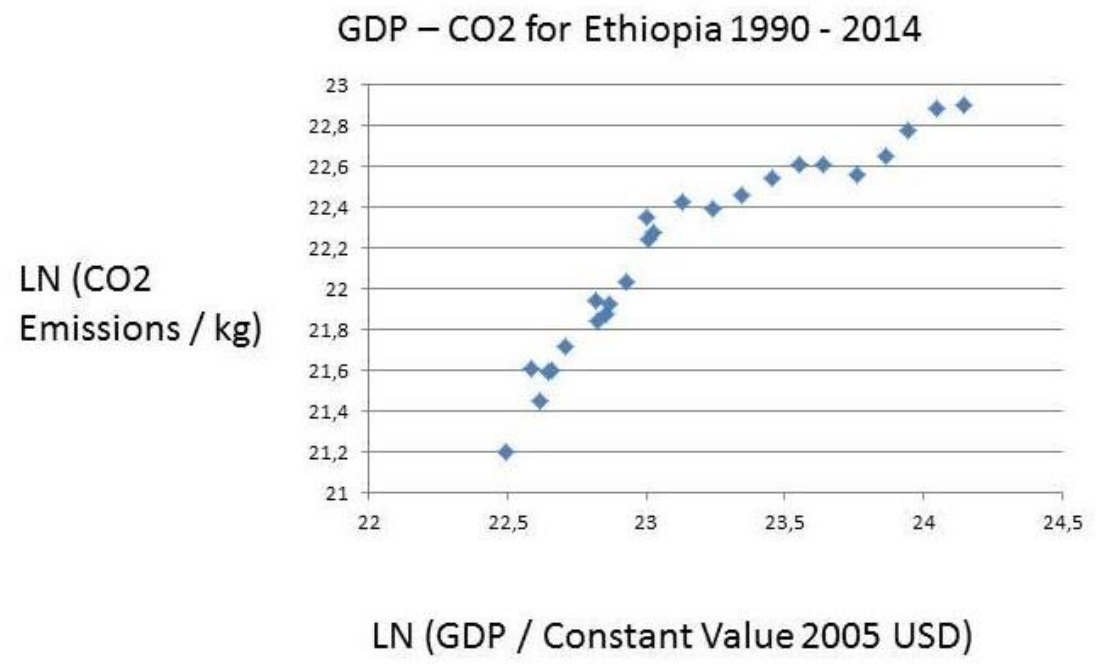

Figure 39. Ethiopia: GDP and CO2: $y=0,90 x, R^{2}=0,88$ 


\section{Ml Macrothink}

Journal of Public Administration and Governance

ISSN 2161-7104

2017, Vol. 7, No. 2

The zest with which Ethiopia is pursuing its control over water resources becomes fully understandable, when Figure 37 is consulted. What we observe is the same smooth linear function plotting CO2:s upon GDP, as is obvious in countries based upon fossil fuels - see below. For Ethiopia, to comply with decarbonisation goals is going to pose major challenges, especially if economic development is not going to be reduced. The country needs massive help, both financially and technologically

\section{Conclusion}

Yet, they do not comprise the implications of lessons of the social sciences for global governance, coordination and policy making. The crux of the matter is what I call the Wildavsky hiatus: policies however appealing are bound to fail when put in practice, as no policy is self-implementable (Pressman and Wildavsky, 1973, 1984). To grasp the feasibility of the COP21 project and its three goals of decarbonisation, one must understand the present giant implementation deficit and the future probabilities of coordination failures. Only a massive investment in solar plants can save mankind from the horrors of climate change.

Table 2, using the giant solar power station in Morocco as the benchmark shows how many solar plants would be needed to replace the energy cut in fossil fuels and maintain the same energy amount, for a few selected countries with big CO2 emissions, according to COP21

Goal 2.

Table 2. Number of Ouarzazate plants necessary in 2030

\begin{tabular}{|l|l|l|l|}
\hline Nation & \multicolumn{1}{|c|}{$\begin{array}{c}\text { Co2 reduction } \\
\text { pledge / } \\
\text { \% of 2005 } \\
\text { emissions }\end{array}$} & $\begin{array}{c}\text { Number of gigantic } \\
\text { solar plants needed } \\
\text { (Ouarzazate) }\end{array}$ & $\begin{array}{c}\text { Gigantic plants } \\
\text { needed for 40 \% } \\
\text { reduction }\end{array}$ \\
\hline United States & $26-28^{1}$ & 2170 & 3100 \\
\hline China & none ${ }^{2}$ & 0 & 8300 \\
\hline EU28 & $41-42$ & 2300 & 2200 \\
\hline India & $n o n e^{2}$ & 0 & 1700 \\
\hline Japan & 26 & 460 & 190 \\
\hline Brazil & 37 & 170 & 170 \\
\hline Indonesia & 29 & 120 & 700 \\
\hline
\end{tabular}

1 America pulled out from the deal in June 2017

${ }^{2}$ China and India has only made pledges in terms of CO2 emissions per GDP, not absolute targets 


\begin{tabular}{|l|l|l|l|}
\hline Canada & 30 & 230 & 300 \\
\hline Mexico & 25 & 120 & 190 \\
\hline Australia & $26-28$ & 130 & 190 \\
\hline Russia & none $^{3}$ & 0 & 940 \\
\hline World & ${\mathrm{N} / \mathrm{A}^{4}}$ & $\mathrm{~N} / \mathrm{A}$ & 16200 \\
\hline
\end{tabular}

NOTE: Average of 250 - 300 days of sunshine used for all entries except Australia, Indonesia, and Mexico, where 300 - 350 was used.

Sources:

Paris 2015: Tracking country climate pledges. Carbon Brief, https://www.carbonbrief.org/paris-2015-tracking-country-climate-pledges

EDGAR v 4.3.2, European Commission, Joint Research Centre (JRC)/PBL Netherlands Environmental Assessment Agency. Emission Database for Global Atmospheric Research (EDGAR), release version 4.3.2. http://edgar.jrc.ec.europe.eu, 2016 forthcoming

CO2 Emission Reduction With Solar

http://www.solarmango.com/in/tools/solar-carbon-emission-reduction

\section{References}

\section{GDP sources:}

World Bank national accounts data - data.worldbank.org

OECD National Accounts data files

\section{GHG and energy sources:}

World Resources Institute CAIT Climate Data Explorer - cait.wri.org

\footnotetext{
${ }^{3}$ Russia made pledge of 25 - $30 \%$ compared to 1990 levels, but this has already been met due to a shrinking economy

${ }^{4}$ Unclear sum of all countries pledges, several nations have interval in their commitments
} 


\section{Macrothink \\ Journal of Public Administration and Governance

EU Joint Research Centre Emission Database for Global Atmospheric

Research - http://edgar.jrc.ec.europa.eu/overview.php

UN Framework Convention on Climate Change -

http://unfccc.int/ghg_data/ghg_data_unfccc/time_series_annex_i/items/3814.php

International Energy Agency. Paris.

Energy Information Administration. Washington, DC.

BP Energy Outlook 2016.

EU Emissions Database for Global Research EDGAR,

http://edgar.jrc.ec.europa.eu/

World Bank Data Indicators, data.worldbank.org

British Petroleum Statistical Review of World Energy 2016

\section{Literature}

Arrhenius, S. A. (1961). Chambers's Encyclopaedia. London: George Newnes, Vol. 1.

Barry, B. (1982). The Tradition of Spontaneous Order. Literature of Liberty, V(2), 7-58. Arlington, VA: Institute for Humane Studies.

Hayek, F. A. (1991). The Fatal Conceit: The Errors of Socialism. The University of Chicago Press.

Kaya, Y., \& Yokoburi, K. (1997). Environment, energy, and economy: Strategies for sustainability. Tokyo: United Nations University Press.

Pressman, J., \& Wildavsky, A. (1973, 1984). Implementation. Berkeley: Univ of Cal: Berkeley.

Rostow, W. W. (1960). The Stages of Economic Growth: A Non-Communist Manifesto. Cambridge: Cambridge University Press

Sachs, J.D. (2015). The Age of Sustainable Development. New York: Columbia University Press.

Schneider, S. (1989). 'Global Warming: Are We Entering the Greenhouse Century?' San Francisco: Sierra Club.

Stern, N. (2007). The Economics of Climate Change. Oxford: OUP.

Stern, N. (2015). What are we waiting for? Cambridge, MA: MIT Press.

Ramesh, J. (2015). Green Signals: Ecology, Growth and Democracy in India (2015). Oxford : Oxford University Press. 


\section{Macrothink}

Journal of Public Administration and Governance

ISSN 2161-7104

2017, Vol. 7, No. 2

\section{Appendix I.}

A model of carbon emissions is the so-called Kaya model. It reads as follows in its standard equation version - Kaya's identity: Kaya's identity projects future carbon emissions on changes in Population (in billions), economic activity as GDP per capita (in thousands of $\$ U S(1990) /$ person year), energy intensity in Watt years / dollar, and carbon intensity of energy as Gton $C \quad$ as $\mathrm{CO}_{2}$ per TeraWatt year." (http://climatemodels.uchicago.edu/kaya/kaya.doc.html). Thus, we have this equation format for the Kaya probabilistic law-like proposition, as follows: (E1) Multiple Regression: $\mathrm{Y}=\mathrm{a}+$ $b_{1} X_{1}{ }^{+} b_{2} X_{2}+b_{3} X_{3}+\ldots+b_{t} X_{t}+u$

Note: $\mathrm{Y}=$ the variable that you are trying to predict (dependent variable); $\mathrm{X}=$ the variable that you are using to predict $\mathrm{Y}$ (independent variable); $\mathrm{a}=$ the intercept; $\mathrm{b}=$ the slope; $\mathrm{u}=\mathrm{the}$ regression

residual.

Note: http://www.investopedia.com/terms/r/regression.asp\#ixzz4Mg4Eyugw.

Using the Kaya model for empirical research on global warming, the following anthropogenic conditions would affect positively carbon emissions: (E2) CO2:s = F(GDP/capita, Population, Energy intensity, Carbon intensity) in a stochastic form with a residual variance, all to be estimated on data from some 59 countries. I make an empirical estimation of this probabilistic Kaya model - the cross-sectional test for 2014: (E3) k1= $0,68, \mathrm{k} 2=0,85, \mathrm{k} 3=0,95, \mathrm{k} 4=0,25 ; \mathrm{R} 2=0.90$.

Note: $\mathrm{LN} \mathrm{CO} 2=\mathrm{k} 1 * \mathrm{LN}(\mathrm{GDP} / \mathrm{Capita})+\mathrm{k} 2 *($ dummy for Energy Intensity $)+\mathrm{k} 3 *(\mathrm{LN}$ Population $)+\mathrm{k} 4 *$ (dummy for Fossil Fuels/all) Dummy for fossils 1 if more than $80 \%$ fossil fuels; $\mathrm{k} 4$ not significantly proven to be non-zero, all others are. $(\mathrm{N}=59)$.

\section{Copyright Disclaimer}

Copyright for this article is retained by the author(s), with first publication rights granted to the journal.

This is an open-access article distributed under the terms and conditions of the Creative Commons Attribution license (http://creativecommons.org/licenses/by/4.0/). 